\title{
Creating Legitimacy for Sustainability Assurance Practices: Evidence from Sustainability Restatements
}

\author{
Giovanna Michelon \\ University of Exeter Business School \\ Streatham Court, Rennes Drive \\ Exeter, UK EX4 4ST \\ G.Michelon@exeter.ac.uk \\ ORCID ID: 0000-0003-0107-9809 \\ Dennis M. Patten \\ Illinois State University \\ Department of Accounting \\ Normal, IL 61761 \\ dmpatte@ilstu.edu \\ Andrea M. Romi (Corresponding Author) \\ Rawls College of Business \\ Texas Tech University \\ Department of Accounting \\ Box 42101 \\ Lubbock, TX 79409-2101 \\ Andrea.Romi@ttu.edu \\ ORCID ID: 0000-0002-4138-0068
}

Accepted by Hervé Stolowy at European Accounting Review

First Submission: June 17, 2017

Final Acceptance: April 20, 2018

Additional materials are available in an online Supplement at the journal's Taylor and Francis website.

\section{Acknowledgements:}

We are very grateful to Hervé Stolowy (the Editor) and the two anonymous Reviewers for the advice and insightful suggestions on our paper. We also appreciate helpful comments from Jill Atkins, Pietro Bonetti, Lies Bouten, Brian Burnett, John Byrd, Chris Chapman, Charles Cho, Jeff Cohen, Kirsten Cook, Yves Gendron, Fani Kalogirou, Bertrand Malsch, Michel Magnan, Linda Myers, Brendan O'Dwyer, Gary Peters, Michelle Rodrigue and George Serafeim, workshop participants at Texas Tech University School of Accounting, Schulich School of Business, the ESSEC Business School, IESEG School of Management, University of Central Florida, $38^{\text {th }}$ EAA Annual Congress, $3^{\text {rd }}$ CSEAR France, $2^{\text {nd }}$ GARI International Conference, $26^{\text {th }}$ International Congress on Social and Environmental Accounting Research, 2014 North American CSEAR, 5 ${ }^{\text {th }}$ Italian CSEAR, and 2014 University of Arkansas Research Conference. Additionally, we are grateful to Andy Leone and Brian Burnett for their generous help with programming and to KPMG for providing us access to the KPMG Survey of Corporate Responsibility Reporting 2013. Finally, we thank Mila Gabana and Kevin Kim for their excellent research assistance. We also gratefully acknowledge the 2014 Best Paper Prize awarded by the PRI Stichting Foundation at the $2^{\text {nd }}$ GARI International Conference (Henley Business School) and financial support from the University of Exeter Firms, Markets and Value Research Cluster and the School of Accounting, Rawls College of Business at Texas Tech University. 


\title{
Creating Legitimacy for Sustainability Assurance Practices: Evidence from Sustainability Restatements
}

\begin{abstract}
:
This study examines sustainability reporting assurance (SRA) provider use of sustainability restatements as a means to create legitimacy in the developing SRA market. In comparison to financial data, mistakes in sustainability reporting are more likely to be made and less likely to be discovered prior to reporting. A lack of clear reporting standards and ambiguous SRA guidelines create a setting where providers can use restatements in an attempt to demonstrate both a problem in sustainability reporting and assurance as the solution to that issue. Based on a sample of U.S. firms from 2010-14, we find that SRA is associated with an increased likelihood of sustainability restatements, that the association is stronger for error restatements than for restatements due to methodological updates, and that SRA is significantly associated with the disclosure of quantitatively non-material restatements. We also document differences in these relations across provider-type, with only consultant assurance significantly associated with methodological restatements and restatements of a non-material amount. Our findings support differences between sustainability report restatements and financial restatements, and provide evidence in support of our argument that assurance providers may be using restatements in an attempt to expand market share in a new professional space.
\end{abstract}

KEYWORDS: sustainability restatements, sustainability assurance services, professionalization, legitimacy. 


\section{Introduction}

The growth in the number of firms issuing stand-alone sustainability reports is well documented among the business community, accounting professionals (KPMG, 2013), and academics alike (e.g. Cho, Michelon, Patten, \& Roberts, 2014; Peters \& Romi, 2015; Unerman, Bebbington, \& O’Dwyer, 2007). Similarly, voluntary external assurance of these documents has also grown (O’Dwyer, 2011; O’Dwyer \& Owen, 2005; Simnett, Nugent, \& Huggins, 2009) with KPMG (2013) reporting 59 percent of the world's largest 250 companies seeking external assurance. Standard setters and stakeholders often assume sustainability reporting assurance (SRA) provides credibility to sustainability information (e.g. Beets \& Souther, 1999; Cho et al., 2014; GRI, 2013; Hodge, Subramaniam, \& Stewart, 2009; O’Dwyer, Unerman, \& Hession, 2005; Peters \& Romi, 2015; Simnett, Vanstraelen, \& Chua, 2009), based on a commonly accepted understanding in the auditing literature that assurance leads to improved discovery of accounting errors prior to reporting, resulting in a negative relationship between audit quality and financial reporting restatements (fewer restatements and improved reporting quality) (e.g. Palmrose \& Scholz, 2004; Pomeroy \& Thornton, 2008).

Critical research questions the assumption that the only goal of SRA is to provide credibility to reporting (Boiral \& Gendron, 2011; O’Dwyer \& Owen, 2005; O’Dwyer, Owen \& Unerman, 2011; Owen, Swift, Bowerman, \& Humphrey, 2000). Rather, as SRA providers attempt to gain market share in a new professional space with significant unmet capacity (Abbott 1988; O’Dwyer et al 2011), different professions must strategically use their current services to create demand (Abbott, 1988; Malsch, 2013). This strategy includes defining a problem within the professional sphere and then producing measurable solutions to legitimate their professional superiority (Abbott, 1988; Boiral \& Gendron, 2011; Gendron \& Barrett, 2004; Malsch, 2013; Power, 1997; 2003). Legitimacy provides the foundation for 
professional jurisdictional claims, while its absence provides a central line for attack from competitors.

Based on Power's (2003) assertion that the legitimacy created by assurance providers, by extension, co-produces legitimacy for the client, we argue that sustainability restatements can be used as a legitimacy co-building tactic. We suggest this possibility exists as a restatement of information from prior sustainability reporting is less likely to be viewed negatively than in financial reporting for various reasons. These reasons include the lack of clear/universally adopted reporting standards (e.g. Boiral \& Gendron, 2011; Collison \& Slomp, 2000), ambiguous SRA guidelines (Moroney \& Trotman, 2016), and underdeveloped or non-existent firm-specific internal sustainability reporting systems, among others. ${ }^{1}$ Further, prior studies (e.g., O’Dwyer et al., 2011) document that co-legitimacy building benefits are communicated in SRA provider-client negotiations during the SRA engagement. If SRA providers successfully alter the meaning of restatements from an indicator of assurance failure, as is the case with financial restatements, to one of improved reporting quality (GRI 2013), it allows them to use restatements as a legitimacy-building tactic. Accordingly, we expect a higher prevalence of restatements in sustainability reports where assurance is in place. We also acknowledge the presence of two distinct SRA provider types, accounting and consulting firms ${ }^{2}$ and we consider whether the differences in their knowledge and skill sets (Huggins et al., 2011; Pflugrath et al., 2011) influence the ways in which they use restatements ${ }^{3}$.

\footnotetext{
${ }^{1}$ Similar to Moroney and Trotman (2016), in the absence of prior literature and clear standards, we rely on professional auditor experience and first-hand knowledge to posit possible challenges facing SRA providers in discovering errors within sustainability reports prior to reporting. Accordingly, we conducted phone interviews with sustainability assurance experts (e.g. leading assurance specialists at the director level within Big 4 auditing firms) prior to conducting our study.

${ }^{2}$ Consultant providers consist mainly of engineering and sustainability service firms (GRI, 2013).

${ }^{3}$ To gain an understanding of the use and attitude toward restatements from a sustainability consultant perspective, we contacted consultant assurance standard developers. Our discussions indicate that the consulting profession similarly views restatements as a tool to report a correction to previously reported inaccurate information; restatements are currently not addressed in the AA1000AS standards; corrections to
} 
Our study explores the use of formal restatements of data within sustainability reports for a sample of U.S. S\&P 500 firms over the period 2010-14. The U.S. is an interesting setting for our analysis in that prior research documents significantly lower assurance rates in the U.S. than in other countries (Cho et al., 2014; Peters \& Romi, 2015), suggesting an enhanced opportunity for assurance providers to work toward expanding their market. This supports Abbott's (1988) claim that investigating the strategies toward gaining market share in a professional space is most relevant when the market is relatively young and expanding, as there is significant untapped capacity to generate profits. Moreover, Abbott (1988) argues that, in the U.S. in particular, it is ultimately through public opinion that professions establish the legitimacy necessary to achieve the rights to a professional space, and the use of restatements to build legitimacy relies on public opinion. We review 1,200 standalone sustainability reports and find 177 that contain at least one restatement, 116 of which include restatements due to error. Contrary to financial reporting restatements and consistent with descriptive evidence in KPMG $(2011 ; 2013)^{4}$ surveys, we find that voluntary assurance of sustainability reports is associated with increased sustainability restatements. We also document that SRA is more strongly associated with restatements due to errors than to methodological updates. Further, and contrary to Moroney and Trotman's (2016) assertion that SRA providers will not consider audit differences below five percent as material, our findings document the presence of restatements even for substantially non-material amounts (we find restatements for values as low as $0.02 \%$ ). Importantly, from a legitimacy-building perspective, we find assurance is significantly related to the disclosure of quantitatively nonmaterial restatements. Finally, while our results indicate both professional accountants and

previous reports should be reported by SRA providers; and that they are currently convening a working group to develop an updated standard.

${ }^{4}$ Our sample differs substantially from KPMG (2013). See our online supplemental material for a reconciliation between the KPMG sample and ours. We reprinted/compiled from The KPMG Survey of Corporate Responsibility Reporting 2013, Copyright: (C) 2013 KPMG International Cooperative ("KPMG International”), a Swiss entity. All rights reserved. 
consultants may be using restatements to build legitimacy for their services, the findings also reveal important differences across SRA providers that may influence the actual or perceived credibility of information. We document the likelihood of restatements due to methodological updates and of non-material amounts relates only to consultant assurance, suggesting the two players in this market demonstrate the legitimacy of their services using different expertise claims. We interpret this finding as evidence that legitimation of professional superiority gains complexity within the SRA arena due to the interprofessional competition between the two main participants, accounting and consulting firms. Hence, we provide insight into the ways each party competes to create legitimacy by both assimilating each other's skills (Abbott 1988), and exploiting their own strength/skill set (Farooq \& De Villiers, 2017; Huggins, Green, \& Simnett, 2011; Pflugrath, Roebuck \& Simnett, 2011; Simnett, Vanstraelen et al., 2009).

All results are robust to a series of additional tests, including a propensity score matching design to minimize the degree of observable heterogeneity between firms seeking assurance and those that do not, consideration of litigation risk, peer effects, and extended assurance tenure. We also provide evidence that restatements are not associated with SRA provider turnover, while they are significantly related to increases in the number of new clients, in line with our arguments that they contribute to legitimacy-building in the assurance market. Overall, our findings suggest sustainability restatements differ from financial restatements, and that, although potentially indicating improved reporting, sustainability restatements may be part of the SRA provider strategy to increase the perceived value of their services.

Our study provides several contributions. First, whereas prior investigations of SRA mainly explore the determinants of the choice to obtain assurance considering institutional, organizational, and governance characteristics (e.g. Beets \& Souther, 1999; Cho et al., 2014; 
GRI, 2013; Hodge et al., 2009; Peters \& Romi, 2015; Simnett, Vanstraelen, et al., 2009), we focus on a potential strategy used by SRA providers to develop legitimacy in a new arena (Gendron \& Barrett, 2004; O’Dwyer, 2011; Power 1997; 2003). Further, while previous studies (e.g., O'Dwyer et al., 2011) explore the process of establishing legitimacy within the SRA arena, we more carefully identify how legitimation tactics appear to vary across the differing provider types, at least in the U.S. setting where SRA remains an underdeveloped and potentially lucrative market. These findings contribute to the theory of professionalization by providing an empirical illustration of the use of a professional task to create legitimacy within a space lacking stringent regulation. We also enhance the theoretical framework of professionalization by showing that professional tasks not only change as a consequence of competition and the professional environment, but that professional groups have the ability to capture a task, participate in diametrically altering its meaning within society, and use this newly defined task to create legitimacy. In the SRA arena, restatements do not mirror the negative connotations they hold within the financial audit context, but instead are used successfully to improve market share. In addition, we offer a different perspective from Moroney and Trotman (2016) by providing archival evidence of a discrepancy between the materiality thresholds used by professional accounting firms and consulting firms. Finally, our study contributes to the understanding of consultant assurer behavior less explored in prior literature, particularly within the accounting domain.

Our findings relating to the differing materiality thresholds across service providers have implications for regulators and standard setters, who in recent years have widely addressed the issue of the credibility of sustainability reporting (IAASB, 2016; AICPA, 2016; WBCSB, 2016; GRI, 2011, 2013; GSSB, 2015; IFAC, 2015). Furthermore, our evidence is important for accounting bodies such as the Sustainability Accounting Standards Board (SASB) and the International Federation of Accountants (IFAC), as they 
focus on defining materiality within sustainability reporting (SASB, 2016; IFAC, 2015) and the London-based Institute of Social and Ethical AccountAbility (AccountAbility), as they have recently convened a working group to develop the next version of the AA1000 assurance standard for non-accountants.

Finally, our research is important for the broad range of users of sustainability reports. While academic research provides evidence of a monitoring role for sustainability reports (Lu, Shailer, \& Yu, 2017) and that sustainability information is value relevant across the world (e.g. Cahan, De Villiers, Jeter, Naiker, \& Van Staden, 2016), we document that these reports may contain material restatements, the effects of which are not clear. At the same time, knowing that restated information within sustainability reports is often non-material, users should question the purpose of these restatements. More broadly, our results also call into question whether restatements are merely a vehicle to create an image that assurance provides value to the reporting process, rather than an actual attempt at transparency and accountability to stakeholders. Understanding this issue is critical as stakeholders increasingly demand sustainability data and desire that the information be credible for decision making (O’Dwyer et al., 2005; Reimsbach, Hahn, \& Gürtürk, 2017).

\section{Background and Hypotheses Development}

\section{Theory of Professionalization and Legitimacy-Building in New Assurance Markets}

While most studies on the development and evolution of professional space in assurance tend to examine only traditional financial auditing (e.g., Coronella, Sargiacomo, \& Walker, 2015; Jeppesen \& Loft, 2011), we explore the issue relative to SRA. Due to its voluntary nature and relatively unregulated status (Boiral \& Gendron, 2011), as well as the significantly high cost to clients (Crespin, 2012), SRA development and expansion as a profit-driver is subject to practitioners' success in creating demand for their services (Power, 2003). The theory of professionalization establishes that developing professional legitimacy is central to 
controlling an emerging professional space (Abbott, 1988). In order for SRA providers to capture the largest market share in a new area, they must create legitimacy for both their service and their particular expertise to provide that service (Power, 1997; 2003). Thus, especially in new areas where techniques have not been realized, assurance is a social construction, requiring elaborate forms of image management (Abbott, 1988; Power, 2003).

Prior literature provides examples of intentional behavior on the part of SRA providers to create an image to both the client and to external parties regarding the legitimacy of SRA services. For example, O’Dwyer et al. (2011) interview practitioners in the sustainability assurance division of a Big 4 professional services firm and find that SRA providers intentionally illustrate the poor quality of their clients' sustainability data to management in order to create legitimacy for SRA services (i.e. client-focused legitimacy-building). O’Dwyer et al. also provide evidence of external or market-based legitimacy-building strategies focused on external parties. In response to concerns of a lack of stakeholder responsiveness to SRA reports, assurance providers altered wording of the assurance statements within the reports.

Abbott (1988) argues that creating legitimacy in a new professional space requires professional groups to define a problem, reason about it, and to provide a measurable, public solution. We propose that formal restatements may be used by SRA providers to enhance the legitimacy of their services by conveying to both the market and the client that SRA is the measurable solution to the problem of inaccurate or unreliable data within the reports (Power, 2003). It is important to stress the distinction between prior sustainability literature relying on legitimacy theory as explaining firms' choices to disclose certain types of information (e.g., Cho, 2009) and the theory of professionalization, where professionals attempt legitimacybuilding to gain access and market share in a new assurance arena (O'Dwyer et al., 2011; Power, 1997; 2003). Suchman (1995, p. 587) notes that "legitimacy building is generally a 
proactive enterprise," and that "innovators who depart from prior practice must often intervene preemptively ... to develop bases of support" (p. 591). Suchman further asserts that pragmatic legitimacy, legitimacy based on constituencies' perceptions of the practical consequences to them from an organization's actions, is the easiest type of legitimacy to manipulate. He refers to this type of manipulation as a form of advertising, whereby the "organization attempts to persuade particular exchange partners to value particular offerings" (Suchman, 1995, p. 591). In our setting, SRA providers may use restatements as a way to initially build pragmatic legitimacy for their services with the goal of expanding market share within the evolving assurance arena.

It is also important to acknowledge that the SRA market includes two main professional groups, auditing firms and consultants (e.g. Perego \& Kolk 2012, O’Dwyer \& Owen 2005; O’Dwyer et al. 2011; Manetti \& Becatti 2009; Simnett, Vanstraelen et al. 2009; Simnett, Nugent, et al., 2009; Casey \& Grenier 2015; Peters \& Romi 2015). Prior literature argues that accounting providers have an advantage with respect to providing high quality assurance given the profession's body of international standards, ethics, independence, and control mechanisms (Pflugrath et al., 2011). In contrast, consulting firms possess significant sustainability expertise but are subject to different standards of professional conduct and independence than the accounting profession (Huggins et al. 2011). However, the assimilation between accountant and consultant assurance providers has increased, largely because the assurance standards each group relies on have become more aligned over time. The ISAE $3000^{5}$ assurance standard, developed by the International Auditing and Assurance Standards Board (IAASB), provides guidance for professional accountants when conducting non-financial assurance engagements (IAASB 2003). The AA1000 Assurance Standard (AA1000AS), developed by AccountAbility, regulates the consulting profession and provides

\footnotetext{
${ }^{5}$ Assurance Engagements Other Than Audits or Reviews of Historical Financial Information.
} 
similar guidance toward SRA engagements. Both standards provide guidance on accepting and performing an engagement, the need for independence and competence, the use of materiality, and the importance of evidence gathering to support reliability and accuracy, among other issues. Neither standard discusses restatements, but professional accountants do have more specific experience with restatements within their financial statement auditing practices. The main difference between the standards lies in the SRA providers' opinion and reporting. Professional accountants are more likely to provide limited levels of assurance and may be narrowly focused on assuring only those items which fit nicely into their conventional financial accounting testing procedures (i.e. numerical indicators) (O’Dywer 2011). Additionally, their SRA services result in significantly greater costs to the assurance purchaser. Consultants, on the other hand, are more likely to provide higher levels of assurance and focus more on providing value to the organization through recommendations for improvements in systems and reporting (Mock, Rao \& Srivastava, 2013). Given that both groups rely on similar standards, but possess different expert skills, differences in the use of restatements to establish legitimacy might exist across provider types.

Of course, the interpretation of restatements as building legitimacy stands in clear contrast to restatements in financial reporting where restatements reflect negatively on the audit provider (e.g., Brocard, Franke, \& Voeller, 2017). In the financial reporting domain, research documents that audit tools and techniques allow for the discovery of financial reporting problems prior to filing, improving the quality of reporting and avoiding restatements in later years (e.g. Palmrose \& Scholz, 2004). In contrast, a number of factors unique to the SRA arena suggest mistakes are more likely to be made, and less likely to be discovered before reporting, even when SRA is present. The whole of these factors potentially lends to SRA providers' ability to use restatements to indicate a positive solution to a public concern about the reporting quality of sustainability information. 


\section{The Unique Nature of Sustainability Restatements in Relation to SRA}

Prior financial accounting literature indicates that the detection of current period errors is more difficult when the reporting and assurance standards are not well defined (Plumlee \& Yohn, 2010). In sustainability reporting, there is ambiguity in both the reporting and in the assurance standards (Boiral \& Gendron, 2011; IAASB, 2016). Further, the transposition of financial auditing practices by professional accountants in the presence of these immature reporting and assurance standards (Moroney \& Trotman, 2016), as well as the development of assurance concepts by sustainability consultants not trained in attestation methods, results in a substantial learning curve (O’Dwyer, 2011). More specifically within accounting firm providers, transposition becomes even more difficult in the face of low levels of sustainability assurance knowledge and high turnover rates among personnel. Anecdotal evidence from discussions with leading SRA providers indicates that accountants, trained to assure financial statements, often find it very difficult to switch over to more challenging engagements where they likely do not have knowledge of the subject matter (also see Delfgaauw, 2000). Further, as knowledge and skills are developed, individuals within the organization often move on to other positions, and the replacement auditors must build that knowledge again. Consultants, on the other hand, do not have the same professional assurance skill set, specifically with respect to error detection during engagement activities, found in the accounting profession, and there may accordingly be less expectation for the discovery of errors by these assurors.

In addition to these factors, detection of errors increasingly becomes difficult because of the limited level of assurance, particularly on the part of accounting firm providers (O’Dwyer, 2011; IAASB, 2016; Perego \& Kolk, 2012), and the under-developed or nonexistent internal sustainability reporting systems and internal control systems associated with sustainability reporting of report-issuing firms (IAASB, 2016). Limited assurance reduces 
engagement risk to a level greater than reasonable assurance and provides for significantly less evidence gathering in terms of amount and quality than reasonable assurance (IAASB, 2013), contributing to difficulties in discovering errors prior to reporting. Further, with less precise auditing standards compared to financial audits (Boiral \& Gendron, 2011), there is less regulatory scrutiny (Moroney \& Trotman, 2016), resulting in a lower risk to reputational harm from assurance results historically perceived as indicating poor audit effort (i.e. restatements).

While we argue the SRA provider is the legitimacy-building strategist involved in the SRA engagement, restatements can also offer clients two potential benefits. First, a restatement provides clients the ability to convey to the public that they are attempting to be transparent and accurate with their information. This argument supports Malsch's (2013) assessment that reputational risk - in our setting associated with inaccurate sustainability information - is managed and converted "as an opportunity provided it is located within the instrumental, demanding but legitimate market relationship between organizations and their consumers" (Malsch, 2013, p. 157). Second, restatements provide the client the ability to demonstrate to top management the need for (or continuation of) assurance services based on the existence of inaccurate data. Accordingly, the use of restatements as an audit legitimacybuilding tool may co-produce legitimacy for both the auditor and the client (Power, 2003), although clients may need to be convinced of the benefits during auditor-client negotiations.

\section{Assurance Provider and Client Negotiations}

Evidence indicates that, when reporting standards are complex and reputation is important, auditors and clients are more likely to discuss and negotiate on issues both in the financial (Gibbins, McCracken, \& Salterio, 2007) and sustainability reporting arenas (Moroney \& Trotman, 2016; O’Dwyer et al., 2011). Central to these negotiations are the client's beliefs about an accounting issue's consequences to themselves and the auditor's 
beliefs about the consequences to the auditor, among others. In relation to sustainability reporting, both the lack of reporting standards and the importance of reputation for both the provider and the client are present, increasing the likelihood that the mutual benefits from disclosing restatements are discussed. Prior auditor-client negotiation research (e.g. Salterio, 2012) reveals that after the discovery of mistakes in reporting, the assurance provider and the client will discuss the mistake and how it ultimately should be handled. O'Dwyer et al. (2011) provide evidence of the assurance provider-client negotiation process in SRA, and document intentional SRA provider legitimizing strategies through discussions with clients.

\section{Hypotheses}

Given the difficulty in discovering errors prior to reporting, the decreased liability associated with SRA engagements due to a lack of clear reporting standards and ambiguous SRA guidelines, and prior evidence of negotiations between SRA providers and clients, we argue that restatements can be used in an attempt to highlight the legitimacy of the SRA provider while also benefiting the clients, rendering a positive relationship between SRA and restatements. Although it is plausible that firms without assurance may also disclose restatements, ${ }^{6}$ we posit that the mutually beneficial legitimation associated with restatements ultimately leads to a greater likelihood of sustainability restatements in the presence of SRA. Accordingly, we anticipate a greater prevalence of restatements in reports with assurance, and we formally state our hypothesis in the alternative form:

\section{H1: The likelihood of having a sustainability restatement is positively associated with the presence of SRA.}

Type of Restatements and SRA

Prior financial reporting research argues it is important to distinguish between restatements due to errors and those due to irregularities because investors and regulators

\footnotetext{
${ }^{6}$ In our discussions with SRA providers, they noted, for example, that some firms without assurance invite stakeholders or advisory groups to provide feedback on their reports, potentially leading to restatements of data. Similarly, other firms rely on their own internal auditing departments to assess the SRA reports, again leading to the potential for restatements.
} 
view irregularities as more severe (e.g. Hennes, Leone, \& Miller, 2008; Lobo \& Zhao, 2013). Similarly, within the sustainability reporting realm, there appear to be two distinct types of sustainability restatements. KPMG (2013) indicates that, among the largest 100 corporations globally, 21 percent of restatements were due to errors (down from 29 percent in 2011), while 79 percent were due to methodological updates (improved methods, updates of scopes, or definitions at 33,20 , and 26 percent respectively). ${ }^{7}$

Restatements due to errors imply a problem within the reporting system (i.e. inaccurate information) while methodological updates have a current period impact that could not have been predicted when prior reports were released (methods change between the reporting years and resulting changes in data are subsequently disclosed for consistency purposes). While the nature of these types of restatements differs, this analysis allows us to distinguish between the possibility that a positive relationship between SRA and restatements reflects a legitimacy-building strategy or the possibility of a learning curve as presented by O'Dwyer (2011).

Methodological updates likely demonstrate improvements being made as a result of SRA efforts (KPMG, 2011) and reflect the 'learning curve' of the SRA process as discussed by O'Dwyer (2011). There would appear to be little risk of harm to either the assurance provider or the client firm from disclosures of restatements due to methodological updates. In contrast, restatements due to errors in prior reporting could reflect poorly on prior assurance efforts at a potential cost to assurance providers. On the other hand, assurance providers could believe restatements related to errors demonstrate that, in the face of significant challenges to reporting and SRA as discussed above, assurance is an important and successful treatment for the risk of misstated information within sustainability reports, and therefore a more powerful legitimacy-building tactic than disclosure of methodological restatements. If restatements are

\footnotetext{
${ }^{7}$ As we identify below, we find that error restatements are more prevalent in our sample of U.S. company sustainability reports. We do not explore in this study what may be driving the difference, but we discuss reconciliation of our findings with those by KPMG (2013) in our online supplemental material.
} 
in fact a legitimacy-building tool, we expect SRA to be positively associated with both methodological and error restatements, but anticipate the relationship will be stronger for the latter. We formally state this hypothesis as:

\section{$\mathrm{H} 2:$ The association between SRA and sustainability restatements is greater for errors than for methodological updates.}

\section{Materiality of Restatements and SRA}

Materiality has long been considered an important factor when examining financial auditing practice (Eilifsen \& Messier, 2015; Messier, 1983; Messier, Mortinov-Bennie, \& Eilifsen, 2005), ${ }^{8}$ but has only recently been considered in relation to SRA (Moroney \& Trotman, 2016). Moroney and Trotman (2016) engage 82 Big 4 audit managers to examine their materiality assessment decisions under a financial versus water engagement. Participants were asked whether failure to correct an audit difference of 6.6 percent $^{9}$ (of relevant base) would render the statement/report materially misstated. Results indicate auditors are more likely to consider the audit difference material in the financial statement audit than in the water assurance engagement. There are two main reasons for this difference. First, Moroney and Trotman (2016) argue that auditors are less likely to have to justify waiving an audit difference above five percent on a SRA engagement because of the ambiguity in materiality threshold. Second, when guidelines are ambiguous, there are fewer incentives for auditors to demonstrate due care by being more conservative. However, if SRA providers are attempting to build legitimacy for their services using restatements, we argue they will take advantage of all opportunities to restate information and will include restatements even when the amounts appear to be quantitatively non-material. Although

\footnotetext{
${ }^{8}$ Within a sustainability-reporting context, the size of the restatement is not a complete proxy for the materiality of the restatement. The GRI defines materiality along two lines: influence on stakeholders' assessments and decisions and significance of the impact. Because we are aware that the first dimension is sovereign to the principle of materiality, we also acknowledge the impossibility, within our archival approach, to assess it. Thus, if anything, the size of the error restatement is only an approximation of the significance of the impact.

${ }^{9}$ Moroney and Trotman (2016) note that five percent of profits before taxes is the most common materiality threshold in financial statement audits (Eilifsen \& Messier, 2015; Libby \& Brown, 2013; Messier et al., 2005), and they argue using an amount below the five percent threshold ran the risk of being considered non-material no matter the qualitative factors presented.
} 
focusing on environmental disclosure as opposed to restatements, Cho, Freedman, and Patten (2012) document that a substantial number of U.S. companies operating in environmentally sensitive industries disclose non-material levels of environmental capital expenditures and that the practice appears to be driven by attempts at legitimation. Relative to report-issuing firms without assurance, therefore, we expect to find a greater prevalence of non-material restatements where assurance is present. We state this hypothesis as:

\section{H3: The likelihood of having a non-material sustainability restatement is positively associated with SRA.}

\section{Sustainability Restatements and SRA providers}

Differences across accountant and consultant assurance providers (O’Dwyer et al., 2005; O'Dwyer, 2011) may lead to differences when attempting to claim the SRA jurisdiction. Prior research on the influence of "expertise" in a given assurance arena indicates claims of expertise are not purely technical, but instead are developed to support the intentions of some parties over others (Power, 1997; Gendron, Cooper, \& Townley, 2007; Malsch, 2013). Additionally, with growing similarities between assurance guidelines between professional accountants and consultants, the less restrictive overall set of standards for consultants (i.e. professional accountants are also guided by their experience with more stringent financial statement auditing standards) may also allow consultants more freedom in the use of restatements toward legitimacy. Relatedly, Moroney and Trotman (2016) call for research examining the differences in outcomes between SRA provider types. Restatements may be a way of differentiating SRA value and building legitimacy in the market by one provider type at the expense of another.

On the other hand, if both professional accountants and consultants are attempting to gain control of the SRA market in its early stages of development, they may both utilize restatements as a legitimizing tactic. In this case, there should be no difference in the 
probability of restatements across provider types. However, it is also possible that the nature and materiality of restatements is affected by the type of SRA provider because of differing expertise, professional background, and the restrictiveness of assurance standard sets.

Without prior literature to distinguish whether different parties attempting to create legitimacy in the same arena will employ similar tactics, we adopt an exploratory approach and provide the following null hypothesis:

H4: The association between the likelihood of having a sustainability restatement and SRA does not vary with the type of SRA provider

\section{Research Method}

\section{Sample and Data Collection}

In line with the theory of professionalization, the maturing SRA market within the U.S. provides a unique setting to gain an understanding of sustainability restatements and their use to develop and promote expertise claims in a market with significant untapped SRA service capacity. Thus, we select our sample from S\&P 500 firms over the period $2010-14 .{ }^{10}$ Similar to prior research, we identify stand-alone sustainability reports using Corporate Register and a review of corporate websites (Peters \& Romi, 2015; Simnett, Vanstraelen, et al. 2009). Table 1, Panel A provides the sample selection, ${ }^{11}$ and Panel B indicates the distribution of sustainability reports over our sample period. The sample appears to be consistently distributed over time.

$$
\text { *** Insert Table } 1 \text { Here*** }
$$

For the purposes of our paper, we define a sustainability restatement as occurring when a firm discloses in the current report that a previous report had an error or omission or that the current report's data is not consistent with the previous report due to methodological updates.

\footnotetext{
${ }^{10}$ With respect to our time period, we rely on the most recent reports available at the time of our data collection, collecting back to 2010 . Using data prior to 2010 is problematic given the reduced availability of voluntary sustainability reports and the minimal use of restatements prior to that time period.

${ }^{11}$ We considered all firms appearing in the S\&P 500 listing for at least one year during the sample period. We then included those firms in all four years, resulting in 2,817 initial observations.
} 
KPMG (2011, 2013) also examines restatements, but instead uses four categories: (1) updates or improved methodology, (2) updates of definitions, (3) updates to scope, and (4) errors or emissions. We found much of the discussion to KPMG's 1, 2, and 3 to be similar in nature, therefore, we combined all of those categories into our 'methodological update' category, which includes things such as increased data availability, changes in reporting scope, and changes in guidelines. Consistent with KPMG (2011; 2013), we did not consider restatements due to acquisitions/divestitures as restating firms in our sample.

We follow a stringent process to identify the existence of restatements in sustainability reports. We first examined a sub-sample of 50 reports to become familiar with commonly used terminology associated with restatements. Using a self-created database of these common words, we next employed PERL ${ }^{12}$ to search each of our sample sustainability reports for mention of any form of: restat*, correct*, updat*, or revis* (e.g. restate, restated, restatement, etc.). PERL captured the paragraph surrounding those particular words, where present, and for each restatement detected ${ }^{13}$, we collected additional information from the sustainability report itself. This information included the type of restatement (e.g., correction of error or methodological update), size of the restatement (i.e. materiality), and the type of data being restated (e.g. environmental). As illustrated in the restatement reported by Baxter in 2011 (see online supplemental material), changes in restated data can be significant. In addition, we collected report-level data with respect to whether GRI was followed and the number of pages in the report. We also relied on PERL to determine the instances of assurance. We searched each sustainability report for any form of the words: assur*, verif*,

\footnotetext{
${ }^{12}$ Practical Extraction and Reporting Language (PERL) is a programming language designed to manipulate and analyze text documents that enables, among other functions, extracting excerpts from those text files and printing reports based on that information.

${ }^{13}$ As a check to our procedure, we manually reviewed the majority of the sustainability reports in our sample for both restatements and assurance and found no cases where the PERL search failed to identify their existence.
} 
accur*, or audit. Where PERL detected assurance, we manually collected information about the assurance and the provider. ${ }^{14}$

\section{The Relationship between Assurance and Restatements}

We use the following logistic regression model to investigate how SRA relates to the likelihood of having restatements disclosed in a particular firm-year report:

$$
\begin{aligned}
& \text { Restatement }_{i, t}=\beta_{0}+\beta_{1} \text { Assurance }_{i, t}+\beta_{2} \text { GRI }_{i, t}+\beta_{3} \text { Report Size }_{i, t}+\beta_{4} \text { Firm Size }_{i, t-1}+ \\
& \beta_{5} \text { Sustainability Performance }_{i, t-1}+\beta_{6} \text { ROA }_{i, t-1}+\beta_{7} L E V_{i, t-1}+\beta_{8} \text { ESSI }_{i}+\text { Year fixed effects }
\end{aligned}
$$

We estimate this model using five alternative measures for restatements. First, we employ a dummy variable (Restatement) equal to 1 if the firm discloses at least one restatement (of any type) in its stand-alone sustainability report for the year, and 0 otherwise. Next, we classify our dependent variable based on the two types of restatements and code the variable 1 where the report contains at least one restatement due to error (methodological update), and 0 otherwise. Finally, we also consider the materiality (non-materiality) of the restatement, and code our dependent variable 1 if the report contains a restatement where the difference in the current report is greater (less) than five percent of the originally reported information, and 0 otherwise. ${ }^{15}$ We also use an indicator variable for our primary test metric, Assurance, and code as 1 firm-year observations where the sustainability report includes external SRA.

\footnotetext{
${ }^{14}$ We note some variation in assurance levels in our sample. We have 59 instances where the level of assurance engagement is not specified, and of the remaining 231 engagements, 179 are limited, 23 are moderate and 29 are reasonable. Un-tabulated analysis shows that the likelihood of restatements is positively associated with the presence of limited and reasonable assurance, but not associated with moderate assurance. Instances of moderate and reasonable assurance are almost completely limited to consultants and likely indicate the same level as limited assurance for professional accountants. Dow's 2013 Sustainability Report addresses this very issue, "In terms of the level of assurance the Company notes that 'limited' as used by ISAE3000 is equivalent to 'moderate' in 1000AS so that this report has a consistent level of assurance as the reports in previous years" (Dow, 2013, p. 43). This makes it difficult to properly determine the assurance level for anything other than limited assurance, which should be consistent across SRA provider types.

${ }^{15}$ Five percent appears to be an acceptable threshold for sustainability reporting as this amount is listed within several sustainability reports in reference to restating information. For example, 3M's sustainability report states, "In every case, 3M adjusts base-year and other years' data if data collection methods change or data errors are identified. Any significant changes in the measurement methods and/or data values applied to key environmental metrics from previous years are documented within the report. Significant changes are defined by 3M's Sustainability Report as changes greater than 5 percent of the original data point." (3M, 2014, p. 138). Another example includes Carnival Corp's report stating, "We adjust data if data collection methods change or data errors are identified. Any significant changes in the measurement methods and/or data values
} 
We include a number of control variables to capture other potential drivers of restatements both at the report and firm level. At the report level, GRI is an indicator variable capturing whether the report follows the GRI guidelines, since the GRI recommends to disclose methodological updates for comparability purposes. We also include Report Size, measured as the number of pages within the report (Loughran \& McDonald, 2014), as a proxy for the extensiveness of reporting since providing more disclosures increases the probability of making mistakes or being impacted by changing methodologies.

We draw firm-level controls from prior research on both SRA and financial restatements. We include Firm Size, measured as the natural log of total sales to control for the size of the firm since literature finds that the size of the firm influences the probability of sustainability reporting and SRA (Casey \& Grenier, 2015; KPMG, 2013; Peters \& Romi, 2015; Simnett, Vanstraelen, et al., 2009), as well as having an impact on auditor liability and, by extension, materiality assessments (Moroney \& Trotman, 2016). Poorly performing firms likely face greater pressures for sustainability information and more heightened stakeholder awareness concerning the reliability of their disclosures. We thus include the control Sustainability Performance. We retrieve sustainability performance data from the KLD database. Because poor performers might face greater exposure to the public (Cho \& Patten, 2007), we measure sustainability performance as the total concerns score. Importantly, in addition to social and environmental concerns, this measure also captures governance concerns ${ }^{16}$.

Prior literature finds that financial performance and risk are associated with financial restatements, thus we include $R O A$ and $L E V$. Finally, firms in environmental and socially sensitive industries endure greater political and social pressures related to sustainability

applied to key metrics from previous years are documented within the report. Significant changes are defined as changes greater than $5 \%$ of the original data point." (Carnival Corp, 2014, p. 10). As a sensitivity check, we repeat all of our analyses using a 10 percent change classification and find that results (un-tabulated) are consistent with those using the five percent cut-off.

${ }^{16} \mathrm{KLD}$ concerns indicate the presence of weaknesses in seven areas: environment, community, corporate governance, diversity, employee relations, human rights, and product responsibility. 
issues and thus may face greater need for reporting accurate information. We employ a dummy variable (ESSI) identifying firms whose primary operations are in an environmental or socially sensitive industry. We classify companies from the chemical, mining, metals, paper, petroleum, and utility industries as environmentally sensitive (Cho \& Patten, 2007) and we also include pharmaceutical, alcoholic beverage, and defense industry firms in this classification due to higher levels of social exposure (Brammer \& Millington, 2005). Finally, we control for year fixed effects and provide robust standard errors, clustering by firm. ${ }^{17}$ Appendix 1 summarizes all variable definitions.

To examine for potential differences across SRA provider type, we estimate our logistic regressions replacing the assurance variable with separate assurance provider type variables, Consultant and Accounting firm, measured as a 1 if the firm purchases external SRA from a consultant or an accounting firm, respectively.

\section{Results}

Overall, we identify 307 restatements, of which 196 are errors and 111 are methodological updates. Due to the restatement pervasiveness (some firms reported more than one restatement in a given year), our total sample originates from only 177 unique reports. As summarized in Table 2, restatements per year increases over our period of investigation, ranging from 10.39 percent of reports with a restatement in 2010 to 21.14 percent of such reports in 2014. This trend provides additional support for the importance of examining this phenomenon within the U.S. setting. Un-tabulated results indicate that most of the restatements relate to environmental (286 restatements) as opposed to social ( 35 restatements) data. Within the environmental category, companies restated greenhouse gas emissions data most often (38.6 percent), followed by energy (17.4 percent), waste (10.0 percent), and water ( 7.8 percent) data. The vast majority of restated social data (65.7 percent

\footnotetext{
${ }^{17}$ Continuous control variables (size, ROA and leverage) are winsorized at the $1 \%$ level.
} 
of the restatements) involved employee indicators related to health and safety issues (accident rates).

$$
\text { ***Insert Table } 2 \text { Here*** }
$$

Table 3, Panel A provides the breakdown of assurance and restatement within our sample reports. Overall, 290 reports (24.2 percent) included assurance, and assurance by consultant $(n=226)$ is more common than assurance by accounting firms $(n=64)$. Focusing on restatement type, 116 reports disclosed at least one restatement due to error and 72 reports had a restatement due to a methodological update (some reports have both an error and a methodological update, therefore the sum is greater than reports with at least one restatement). We also find 85 (98) reports disclosing a restatement greater (less) than five percent, including restatements as low as $0.02 \%$ of underlying base. The size of the restatement is not reported in 39 cases, and as such, the number of observations for the materiality tests drops from 1,200 to 1,161 .

Table 3, Panel B presents a comparison of the prevalence of sustainability restatements across assured and non-assured reports. In each case, the proportion of sample reports containing the specific restatement of interest is larger for the assurance sub-sample of firms than for the non-assured counterparts, and results of Chi-squared tests indicate the differences in proportions across these groups is statistically significant (at $p<.001$, one-tailed).

$$
\text { ***Insert Table } 3 \text { Here*** }
$$

Table 4, Panel A provides descriptive statistics for control variables used in our multivariate analysis. As indicated, 52.3 percent of reports follow GRI guidelines, and 28.7 percent of the observations come from firms in socially or environmentally sensitive industries. On average, the reports are approximately 59 pages in length, but vary across a wide range $(\min =2, \max =581)$. As expected given our focus on $S \& P 500$ companies, firms are relatively large and profitable. Sustainability performance scores range from zero to 18 , 
with a mean of 3.093. Table 4, Panel B reports the correlation analysis and provides preliminary evidence that restatements are positively associated with SRA.

$$
\text { ***Insert Table } 4 \text { Here }{ }^{* * *}
$$

Table 5 provides the results of our logistic regression analyses when considering the likelihood of disclosing any type of restatement (column 1), errors (column 2), methodological updates (column 3), material (column 4), and non-material (column 5) restatements. We find that SRA is positively and significantly related to the likelihood of a restatement (at $p<.01$ ), supporting $\mathrm{H} 1^{18}$. This result, in combination with the results in columns 2, 3, and 5 provide support to our argument that sustainability restatements are a legitimizing tactic. Specifically, while SRA is positively and significantly related to the likelihood of both an error restatement (at $p<.01$ ) and a restatement due to methodological update (at $p<0.10$ ), the coefficient on Assurance is significantly larger in magnitude for the error restatement regression model. Specifically, the odds of disclosing an error for firms with SRA (un-tabulated) are about 3.77 times higher than the odds for firms without SRA, while the odds of disclosing a restatement due to a methodological update for firms with SRA are only 1.72 times higher than the odds for firms without SRA. This supports H2. Further, the results reported in column 5 provide evidence on H3. SRA is positively associated with non-material restatements, and the odds of disclosing such a restatement are 2.80 times (untabulated) higher when assurance is present than when it is not. The finding that assurance is associated with non-material restatements suggests SRA providers see benefit in restating insignificant amounts, which, we argue, is consistent with attempts at building professional legitimacy. Finally, although not part of our hypothesis tests, the results presented in column 4 indicate material restatements are also significantly associated with the presence of SRA.

\footnotetext{
${ }^{18}$ We note that for the 99 reports with restatements and assurance, we have 72 instances where the indicators being restated are specifically assured within the report and 25 restatements that instead relate to indicators that are not assured within the report (in two cases we were not able to assess whether the specific item being restated is covered by assurance).
} 
With respect to the control variables, we find that both the extensiveness of reporting (Report Size) and the use of the GRI increase the likelihood of restatements of all types, where we find that the size of the firm is only significant when we analyze error restatements. Additionally, higher leveraged firms are statistically less likely to report methodological updates. Our ESSI variable is not significant in any model specifications.

$$
\text { ***Insert Table } 5 \text { Here*** }
$$

Table 6 reports the analysis for H4. Column 1 indicates that the likelihood of disclosing any restatement is positively associated with SRA provided by both consultants and accounting firms. Furthermore, the two coefficients are not statistically different from one another (un-tabulated), indicating that both types of SRA providers are equally likely to support the use of restatements. However, examination of the nature and materiality of restatements reveals important differences. First, while the likelihood of disclosing errors is positively (and equally) associated with both SRA provider types, the likelihood of disclosing a restatement due to methodological updates is only statistically significant for consultant providers. This may be an indication of the learning curve as proposed by O'Dwyer (2011) and KPMG (2011). On the other hand, this could also indicate the expertise claims of one party against another (Abbott, 1988; Malsch, 2013; Power, 1997). As these two parties try to gain control of the SRA market within the U.S., the need to claim expertise in SRA grows and consultants could be using methodological updates to identify a problem and a solution, where professional accountants, restricted more by their historical financial statement assurance standards, use errors. However, the relatively low level of significance $(<.10$, twotailed) suggests such an interpretation is speculative as opposed to absolute.

Second, in contrast to firms with consultant assurance, firms with SRA provided by accounting firms are not more likely to disclose a non-material restatement than firms without assurance. This likely reflects the restrictive differences in SRA standard sets 
between the two parties. While both provider assurance standards contain materiality

guidance, professional accountants face additional historically stable materiality thresholds

within the financial reporting arena. Less restrictive assurance standards allow consultants to use non-material and material restatements similarly. These two results, in combination, suggest the use of different expertise claims of one party versus the other within the SRA arena in the U.S. ${ }^{19}$

*** Insert Table 6 Here***

Additional Analysis ${ }^{20}$

\section{Ruling out alternative explanations}

Given that SRA is voluntary, we acknowledge that our models may suffer from selfselection bias. In order to minimize the degree of observable heterogeneity between firms with and without SRA, we employ a propensity score matching design (Blundell \& CostaDias, 2009). We thus obtain a sub-sample of firms in which the treated (assurance) and the control group are as comparable as possible on a number of observable characteristics. ${ }^{21} \mathrm{We}$ select matching variables using Peters and Romi’s (2015) model for determinants of assurance (see Appendix 1 for variable descriptions). We match each firm to the closest (caliper 0.03) neighbor with no replacement. The sample is reduced to 372 (186) total (treated, i.e. with assurance) firm-year observations. Table 7, Panel A reports the means for the treated and control group for each of the covariates included in the propensity score

\footnotetext{
${ }^{19}$ We also analyze whether the effects of assurance differ in relation to instances of restatements negatively impacting prior performance (e.g. restated greenhouse gas emissions where prior reports were understated) versus restatements improving prior performance (e.g. restated employee accident rates which were previously overstated). Overall, we find that SRA services do not differentiate between the disclosures of positive or negative restatements (i.e. are likely to impact both) and that the provider type (accountant versus consultant) does not change this result.

${ }^{20}$ For the sake of brevity, not all of the additional tests (presented to the reviewers) are tabulated.

${ }^{21}$ Although propensity score matching does not solve for self-selection bias due to unobservable factors, nor does it necessarily solve endogeneity concerns over omitted correlated variables, it deals with the selection process by constructing a control group of firms with observable characteristics similar to the treated. In other words, it identifies the correct sample counterpart for the missing information on the treated outcomes, had they not been treated, by pairing each participant with members of the control group. Under this matching assumption, the only remaining difference between the two groups is the SRA adoption.
} 
matching. Panel B reports the logistic regressions performed on the propensity scored matched sample for all dependent variables and supports the inference of the main analysis in that assurance is positively and significantly associated with the presence of restatements, errors, methodological updates, material, and non-material restatements for this reduced sample. $^{22}$

***Insert Table 7 Here***

We next consider the effect of first time adoption of assurance vs. continuing assurance engagements. Given the difficulties discovering mistakes prior to reporting, if restatements help firms and providers create legitimacy for their reporting and services, respectively, we would anticipate providers to be motivated to disclose restatements for both initial and continuing engagements. We find that first-year SRA is significantly associated with restatements of previously reported information, as is continuing SRA (un-tabulated), indicating first-time assurance is not driving our results ${ }^{23}$.

We further analyze whether concerns with potential litigation could be driving the restatement decisions by firms and/or the assurance providers. Hence, we include a litigation risk indicator variable and re-estimate regressions using each of our restatement classifications. We rely on seven measures for litigation risk, based on prior literature: Francis, Philbrick, and Schipper's (1994) dichotomous measure based on firms in SIC does 2833-2836, 3570-3577, 7370-7374, 3600-3674, 5200-5961, and 8731-8734, and Kim and

\footnotetext{
${ }^{22} \mathrm{We}$ also incorporate a two-stage regression model. For the first stage, we model the likelihood of providing SRA following Peters and Romi (2015), with the addition of a firm's inclusion in a sustainability index. In the second stage, the coefficient for assurance remains significant and the Wald test is not significant.

${ }^{23}$ We also run multivariate analyses that consider a change approach for the first-time adoption of GRI vs. continuing GRI reporting across various measures of restatements, controlling for both presence of SRA or, alternatively, adopting a change approach and controlling for first-time adoption of SRA and continuing SRA engagement. While our main evidence on SRA remains unaltered, we find that firms restate in compliance with the comparability principle as they continue to report in accordance with the GRI guidelines rather than when adopting the GRI. These tests indicate that it is assurance, rather than GRI, that seems to be the main driver of our results. Finally, we consider a lagged model, to test the association between the likelihood of restating in year $t$ and the presence of assurance in year ( $\mathrm{t}-1)$. We find this coefficient to be significant and positive. However, when we include both the concurrent and lagged variable for assurance, the coefficient of the lagged variable is no longer significant, suggesting that it is the presence of assurance in the reporting year that drives the disclosure of restatements.
} 
Skinner's (2012) measures associated with future litigation: lagged size, lagged marketadjusted 12-month stock return, lagged 12-month return skewness, lagged 12-month return standard deviation, lagged sales growth, and lagged trading volume turnover. Un-tabulated results indicate that the only litigation risk variable systematically associated with restatements is return skewness, and, except for the model using methodological updates, assurance remains positive and significant. Thus, although we cannot completely rule out the possibility that litigation concerns play a role in the restatement decision, our evidence suggests this is not the case ${ }^{24}$.

Another factor potentially driving our results is mimicking behaviors among peers (Boiral \& Gendron, 2011; Cormier, Magnan, \& Van Velthoven, 2005; Pfarrer, Smith, Bartol, Khanin, \& Zhan, 2008). We examine this possibility by constructing a variable equal to the proportion of peers restating within an industry in the year prior to the restatement. We subsequently partition the sample according to whether this variable is equal to or great than zero, with High Peer Effects reflecting firms with a larger number of peers providing restatements in the prior period. Un-tabulated results indicate no difference in restatement behavior across firms facing high or low social forces. All other results remain similar to our primary analysis ${ }^{25}$.

\section{Impact on the assurance provider}

If restatements lead to negative outcomes for assurance providers, it would be unlikely they are seen and used as legitimacy-building tools. We first explore this possibility by

\footnotetext{
${ }^{24}$ To further explore potential assurer concerns regarding litigation risk, we focus on material restatements as these would most likely raise litigation issues. We add a high litigation industry risk and assurance interaction variable to assess whether the likelihood of having material restatements is greater when assurance is present for firms facing higher litigation risk. Un-tabulated results show that neither the litigation risk variable nor the interaction term is statistically significant and assurance continues to be positively and significantly associated with the restatements.

${ }^{25}$ To further rule out other potential factors we also run models controlling for the presence of financial restatements as a proxy for overall reporting quality, a variety of governance factors drawn from Peters and Romi (2015), and an alternative classification of industry risk drawn from Simnett, Vanstraelen, et al. (2009). In all cases, results remain qualitatively similar to the main analyses. Results also remain comparable when models include industry fixed effects, and when we consider separately firms providing SRA for the entire report or only over specific items such as environmental metrics.
} 
considering the legitimacy of the SRA provider within their existing clients and investigate the likelihood to retain the SRA provider in the year following a restatement. We use a one/zero indicator variable to identify firm years where a client retains the same assurer from the previous report. We regress this variable respectively on the presence of a restatement, error or methodological update, and material or non-material restatements. As documented in Table 8, Panel A, we find the presence of a restatement in year t- 1 is positively associated with the likelihood to retain the same SRA provider in year t (column 1). The analyses on more specific aspects of the restatements, error versus methodological in column 2, and material versus non-material in column 3 , show only material restatements as being significantly related to retention. However, the lack of a significant negative relation indicates the client is not more likely to change provider following any type of restatement. Broadly speaking, these findings are contrary to evidence in prior auditing literature where financial restatements are associated with auditor turnover, and support our argument that restatements may be used to highlight the value of the assurance service.

$$
\text { ***Insert Table } 8 \text { here*** }
$$

Second, we test impacts associated with the non-client market. If sustainability restatements increase the legitimacy of the SRA provider's services, we would expect to see an increase in demand for its services from external users. We conduct this analysis at the provider level and use our pool of observations over the 2010-2014 period. We create an indicator variable where one designates an increase in a provider's number of assurance clients relative to the prior year. If the number of clients decreases or remains unchanged, we code the variable as zero. We regress our client increase variable on the presence of a restatement in any report assured by the given assurance provider in the previous period, and we test this across all categories of restatement. We also control for assurer type and year fixed effects. As indicated in Table 8, Panel B, restatements, overall, are positively and 
significantly associated with increases in assurance clients in the subsequent period. With respect to specific types of restatements, our results indicate that both methodological and material restatements are positively and significantly related to increases in clients. In contrast, error restatements and non-material restatements, although positively signed, are not significant at conventional levels. Overall, our analyses suggest restatements are not leading to negative impacts for assurance providers, and may be enhancing legitimacy with respect to client retention and growth.

\section{Impacts on clients}

Finally, if restatements lead to negative effects for client firms, it would again be unlikely that the clients would agree to their disclosure. Given that prior research documents that investors react negatively to financial restatements, we explore the market reactions to sustainability restatements. Relying on Lexis-Nexis and broad internet searches, we are able to isolate the report release date for 484 of our sample sustainability reports, 92 of which contain a restatement. Following Guidry and Patten (2010), we use a market-adjusted model based on an equally weighted index to estimate abnormal returns over a three-day window. For each report, we subtract the CRSP market index return from the company's daily return to obtain the market-adjusted abnormal return for the three trading days $(-1,0,+1)$ surrounding the release date. We sum the daily abnormal returns to calculate the cumulative abnormal return (CAR) for each release and test for differences across reports with and without restatements. Results (un-tabulated) show no significant differences, indicating the market does not penalize firms for disclosing sustainability restatements, again lending credence to our argument that restatements can be used as a legitimacy-building tool.

\section{Discussion and conclusion}

As the importance of sustainability information in assessing firm-specific value creation and future economic prospects increases (WBCSD, 2016; GRI, 2011; 2013; GSSB, 2015; 
SASB, 2016; IAASB, 2016; AICPA, 2016), understanding sustainability restatements becomes imperative. We rely on the theory of professionalization as a framework to examine sustainability restatements. Theory argues that assurance providers attempting to gain market share in a new service arena must first create legitimacy for their services, and we posit that sustainability restatements serve to enhance both the credibility of report-issuing firms' commitment to sustainability and the legitimacy of SRA services. Based on a large sample of standalone sustainability reports issued by U.S. firms from 2010 through 2014, we find that the presence of restatements is positively associated with SRA. We document that this relation holds more strongly for errors as opposed to methodological updates, and that assurance is significantly associated with the presence of quantitatively non-material restatements. Our results thus support the argument that, as the SRA profession attempts to gain market share in a new space, assurance providers appear to use formal restatements to reveal both a problem associated with sustainability reporting (inaccurate data) and a solution to that problem (SRA services) represented by restatements, while allowing clients to portray to stakeholders an image of transparency, hence co-building legitimacy. We also find that legitimizing tactics differ across SRA provider types. Consultants are more likely to disclose both methodological updates and non-material restatements, the latter likely indicating the restrictions professional accountants face with respect to historical financial statement auditing standards. Our evidence supports Malsch's (2013) claims that firm-specific sustainability practices, focused on business risks as a way to gain an economic advantage in the market, foster SRA's development of new services.

Our findings provide several contributions to the literature. First, we provide an empirical illustration of a new form of legitimacy used within the U.S. SRA market, one that is used differently by the two main provider types. Additionally, our study contributes to the understanding of consultant assurer behavior which has received less attention in prior 
accounting literature. We also contribute to Moroney and Trotman's (2016) experimental work on the materiality thresholds within the SRA domain. They find that accountant SRA providers do not consider audit differences below five percent as material, and our empirical results support this finding. However, we add to their findings by providing evidence that consultants do provide restatements for non-material amounts (and for updates to methodology). We argue that the differences likely represent the use of all forms of restatements by consultants, who control the market in the U.S. (contrary to the global market), to potentially defend their competitive position and gain additional market share in this unique space.

Our study also enhances the theoretical framework we rely on. The theory of professionalization prescribes that the tasks of professions are vulnerable to changes in the development of the profession and to changes in society (Abbott, 1988). We find that, not only do tasks change as a consequence of a new professional environment, but that professional groups appear to have the ability to diametrically alter the meaning of tasks in order to create legitimacy for their services within a new professional space. While restatements are commonly accepted evidence of audit failure within the auditing professional space (consultants have no prior experience with assurance provision), the ambiguous guidelines for reporting and assurance provision within the new SRA arena allow SRA providers to socially transform restatements into a representative solution to the problem associated with the quality of sustainability reporting. As such, they create legitimacy and demand for their services. Furthermore, our findings speak to the concept of interprofessional competition among different groups vying for a new professional space. To the extent that a profession (in our case, professional accountants) specifies the admissible type of evidence of solutions (restatements), it risks competition with groups whose overall set of standards are less restrictive (consultants) (Abbott 1988). This less restricted group can 
then more easily assimilate those skills and solve problems to improve their legitimacy within the arena as well, increasing competition and claims to the new professional space. Our research contributes to the understanding of the assimilation of SRA practices between professional groups and the use of differences in professional skill sets to adopt divergent strategies involving restatements.

While we believe SRA providers may be using restatements to their advantage with respect to the development of the profession, we also acknowledge that the relative newness of the field plays a role in their ability to do so. Immature reporting and assurance standards in combination with the transfer of financial auditing practices by professional accountants and the development of assurance concepts by sustainability consultants likely result in a substantial learning curve (O’Dwyer, 2011). Further, providers may face difficulties in discovering errors prior to reporting because of under-developed or non-existent internal reporting systems and internal control systems for sustainability within firms, and, at least in some cases, the fact that SRA only offers a limited level of assurance. At the same time, providers are somewhat insured against reputational harm from the disclosure of restated information due to these factors. SRA providers face less public scrutiny of assurance effort than financial statement auditors due to the ambiguity in assurance standards across the two types of engagements, and sustainability restatements receive less unfavorable attention than financial restatements.

Claims to a new professional space develop over a long period of time (Abbott, 1988). As reporting standards become more fine-tuned, reporting systems within organizations strengthen, auditing training includes sustainability, and more stringent controls are developed to assist with more efficient reporting, SRA providers will face a more pervasive reporting process, rendering more consistency in their services, and presumably, less opportunity to use restatements as a legitimizing tool. At the same time, this iterative learning 
process, perhaps partly fueled by the ability to use restated data, may indeed be leading to the provision of better, more meaningful information through sustainability reporting. We leave investigation of that possibility to future research.

Our findings suggest other potentially interesting extensions. Future research could focus on countries where reporting and SRA have a longer tenure and history and where the institutional environment (such as, for example, the level of litigation or the maturity of the SRA market) may lead to different insights. Given our findings on the restatement of nonmaterial information, future research could also explore how differing types and levels of restatement influence stakeholders' assessments and decisions. Similarly, exploring whether the practice of restating sustainability information improves management's accountability to stakeholders could provide additional understanding of the impact of SRA on firm behavior.

As with all studies, ours suffers from certain limitations. First, we cannot identify firms that may restate information but do not disclose that they have done so, nor can we assess whether assurance impacts such decisions. Second, Ballou, Casey, Grenier, and Heitger (2012) report that some firms obtaining assurance do not publicly report this information and we cannot assess the degree to which such behavior may alter our results. Third, we focus on one country and a limited time-series. We cannot completely disentangle whether restatements are a co-produced legitimacy tactic on the part of SRA providers and firms, or just a natural consequence of the early stage of SRA in the U.S, or both. We believe our analysis is rigorous and points towards restatements used as a legitimacy building tool, based on differences across the type and size of restatements when SRA is present. Finally, while we employ a variety of sensitivity tests to address potential factors influencing the relations we report, we cannot completely rule out that some time-variant unobservable characteristics are driving our results. 


\section{References}

3M. (2014). 3M 2014 Sustainability Report: Innovation Improving Lives. 3M. Maplewood, Minnesota.

Abbott, A. (1988). The System of Professions: An Essay on the Division of Expert Labor. Chicago: The University of Chicago Press.

American Institute of Certified Public Accountants (AICPA). 2016. Discussion Memo: Draft Sustainability Attestation Standard. ASB Meeting - ASB Sustainability Task Force, AICPA, Durham, NC.

Ballou, B., R. Casey, J. Grenier, \& Heitger, D. (2012). Exploring the strategic integration of sustainability initiatives: Opportunities for accounting research. Accounting Horizons, 26 (2), 265-288.

Baxter. (2011). Baxter 2011 Sustainability Report. Baxter International, Inc. Deerfield, IL.

Beets, S. D., \& Souther, C. C. (1999). Corporate environmental reports: The need for standards and an environmental assurance service. Accounting Horizons, 13 (2), 129-145.

Blundell, R., \& Costa-Dias, M. (2009). Alternative approaches to evaluation in empirical microeconomics. Journal of Human Resources, 44 (3), 565-640.

Boiral, O., \& Gendron, Y. (2011). Sustainable development and certification practices: Lessons learned and prospects. Business Strategy and the Environment, 20: 331-347.

Brammer, S., \& Millington, A. (2005). Corporate reputation and philanthropy: An empirical analysis. Journal of Business Ethics, 61 (1), 29-44.

Brocard, M., Franke, B., \& Voeller, D. (2017). Enforcement actions and auditor changes. European Accounting Review. DOI: 10.1080/09638180.2017.1307130

Cahan, S.F., De Villiers, C., Jeter, D.C. Naiker, V. \& Van Staden, C.J. (2016). Are CSR Disclosures Value Relevant? Cross-Country Evidence, European Accounting Review, 25 (3), 579-611

Carnival Corp. (2014). From Ship to Shore: FY 2014 Sustainability Report. Carnival Corporation \& plc. Miami, FL.

Casey, R. J., \& Grenier, J. H. (2015). Understanding and contributing to the enigma of corporate social responsibility (CSR) assurance in the United States. Auditing: A Journal of Practice \& Theory, 34 (1), 97-130.

Cho, C.H. (2009). Legitimation strategies used in response to environmental disaster: a French case study of Total SA's Erika and AZF incidents. European Accounting Review, 18(1), 3362 .

Cho, C. H., Freedman, M., \& Patten, D. M. (2012). Corporate disclosure of environmental capital expenditures: a test of alternative theories. Accounting, Auditing and Accountability Journal, 25(3), 486-507.

Cho, C. H., Michelon, G., Patten, D. M. \& Roberts, R. W. (2014). CSR report assurance in the USA: An empirical investigation of determinants and effects. Sustainability Accounting, Management and Policy Journal, 5 (2), 130-148.

Cho, C. H., \& Patten, D.M. (2007). The role of environmental disclosures as a tool of legitimacy: A research note. Accounting, Organizations and Society, 32 (7-8), 639-647. 
Collinson, D. \& Slomp, S. (2000). Environmental accounting, auditing and reporting in Europe: the role of FEE. European Accounting Review, 9(1), 111-129.

Coronella, S., Sargiacomo, M. \& Walker, S. P. (2015). Unification and dual closure in the Italian accountancy profession, 1861-1906. European Accounting Review, 24 (1), 167-197.

Cormier, D., Magnan, M. \& Van Velthoven, B. (2005). Environmental disclosure quality in large German companies: economic incentives, public pressures or institutional conditions? European Accounting Review, 14(1), 3-39.

Crespin, R. J. (2012). What Price Assurance? March 6. Available online at http://www.thecro.com/topics/business-ethics/what-price-assurance/, retrieved January 15 , 2016.

Delfgaauw, T. (2000). Reporting on Sustainable Development: A Preparer's View. Auditing: A Journal of Practice \& Theory, 19 (supplement), 68-74.

Dow. (2013). 2013 Annual Sustainability Report. The Dow Chemical Company. Midland, MI

Eilifsen, A., \& Messier, W. F. Jr. (2015). Materiality guidance of the major public accounting firms. Auditing: A Journal of Practice \& Theory, 34 (2), 3-26.

Farooq, M. B. and De Villiers, C. (2017). The market for sustainability assurance services: A comprehensive review of the literature and future avenues for research. Pacific Accounting Review, 29 (1), 79-106.

Francis, J., Philbrick, D. \& Schipper, K. (1994). Shareholder litigation and corporate disclosures. Journal of Accounting Research, 32 (2), 137-164.

Gendron, Y. \& Barrett, M. (2004). Professionalization in action: Accountants' attempt at building a network of support for the WebTrust Seal of Assurance. Contemporary Accounting Research, 21 (3), 563-602.

Gendron, Y., Cooper, D. J. \& Townley, B. (2007). The construction of auditing expertise in measuring government performance. Accounting, Organizations and Society, 32: 101-129.

General Mills. (2014). General Mills Global Responsibility 2014. General Mills, Minneapolis, MN.

Gibbins, M., McCracken, S. A. \& Salterio, S. E. (2007). The Chief Officer's perspective on auditor-client negotiations. Contemporary Accounting Research, 24 (2), 387-422.

Global Reporting Initiative (GRI). (2011). Sustainability Reporting Guidelines. Global Reporting Initiative, Amsterdam, Netherlands. Available online at https://www.globalreporting.org/resourcelibrary/G3.1-Guidelines-Incl-Technical-Protocol.pdf

Global Reporting Initiative (GRI). (2013). The external assurance of sustainability reporting. Global Reporting Initiative, Amsterdam, Netherlands. Available online at https://www.globalreporting.org/resourcelibrary/GRI-Assurance.pdf

Global Sustainability Standards Board (GSSB). (2015). Enhancing credibility and trust of sustainability reporting. GRI-GSSB, Amsterdam, Netherlands.

Guidry, R.P. \& Patten, D.M. (2010). Market reactions to the first-time issuance of corporate sustainability reports: Evidence that quality matters. Sustainability Accounting Management and Policy Journal, 1(1): 33-50

Hennes, K. M., Leone, A. J. \& Miller, B. P. (2008). The importance of distinguishing errors from irregularities in restatement research: The case of restatements and CEO/CFO turnover. The Accounting Review, 83 (6), 1487-1519. 
Hodge, K., Subramaniam, N. \& Stewart, J.. (2009). Assurance of sustainability reports: Impact on report users' confidence and perceptions of information credibility. Australian Accounting Review, 19 (3), 178-194.

Huggins, A., Green, W. J., and Simnett, R. (2011). The competitive market for assurance engagements on greenhouse gas statements: Is there a role for assurers form the accounting profession? Current Issues in Auditing, 5 (2), A1-A12.

International Auditing \& Assurance Standards Board (IAASB). (2013). International Standard on Assurance Engagements: ISAE 3000 (Revised), Assurance Engagements Other than Audits or Reviews of Historical Financial Information, International Federation of Accountants: New York.

International Auditing \& Assurance Standards Board (IAASB). (2016). Discussion Paper: Supporting credibility and trust in emerging forms of external reporting: Ten key challenges for assurance engagements, International Auditing and Assurance Standards Board: New York.

International Federation of Accountants (IFAC). (2015). Materiality in IR: Guidance for the preparation of integrated reports, International Federation of Accountants: New York.

Jeppesen, K. K. \& Loft, A. (2011). Regulating audit in Europe: the case of the implementation of the EU Eighth Directive in Denmark, 1984-2006. European Accounting Review, 20 (2), 321-354.

Kim, I. \& Skinner, D.J. (2012). Measuring securities litigation risk. Journal of Accounting and Economics 53, 290-310.

KPMG. (2011). KPMG international: The KPMG survey of corporate responsibility reporting 2011. KPMG International Cooperative 2011. Available online at https://www.kpmg.com/PT/pt/IssuesAndInsights/Documents/corporateresponsibility2011.pdf

KPMG. (2013). KPMG international: The KPMG survey of corporate responsibility reporting 2013. KPMG International Cooperative 2013. Available online at http://www.kpmg.com/Global/en/IssuesAndInsights/ArticlesPublications/corporateresponsibility/Documents/kpmg-survey-of-corporate-responsibility-reporting-2013.pdf

Libby, R., \& Brown, T. (2013). Financial statement disaggregation decisions and auditors' tolerance for misstatement. The Accounting Review, 88 (2), 641-665.

Lobo, G. J., \& Zhao, Y. (2013). Relation between audit effort and financial report misstatements: Evidence from quarterly and annual restatements. The Accounting Review, 88 (4), 1385-1412.

Loughran, T., \& McDonald, B. (2014). Measuring readability in financial disclosures. The Journal of Finance, 69 (4), 1643-1671.

Lu, L.Y., Shailer, G. \& Yu, Y. (2017) Corporate Social Responsibility Disclosure and the Value of Cash Holdings, European Accounting Review, 26 (4), 729-753

Malsch, B. (2013). Politicizing the expertise of the accounting industry in the realm of corporate social responsibility. Accounting, Organizations and Society, 38: 149-168.

Manetti, G., \& Becatti, L. (2009). Assurance services for sustainability reports: Standards and empirical evidence. Journal of Business Ethics, 87 (1), 289-298.

Messier, W. F. Jr. (1983). The effect of experience and firm type on materiality/disclosure judgements. Journal of Accounting Research, 21 (2), 611-618. 
Messier, W. F. Jr., Martinov-Bennie, N. \& Eilifsen, A. (2005). A review and integration of empirical research on materiality: Two decades later. Auditing: A Journal of Practice \& Theory, 24 (2), 153-187.

Mock, T. J., Rao, S. S. \& Srivastava, R. P. (2013). The development of worldwide sustainability reporting assurance." Australian Accounting Review 23 (4), 280-294.

Moroney, R., \& Trotman, K. T. (2016). Differences in auditors' materiality assessments when auditing financial statements and sustainability reports. Contemporary Accounting Research, $33(2), 551-575$.

O'Dwyer, B. (2011). The case of sustainability assurance: Constructing a new assurance service. Contemporary Accounting Research, 28 (4), 1230-1266.

O’Dwyer, B., \& Owen, D. (2005). Assurance statement practice in environmental, social and sustainability reporting: A critical evaluation. The British Accounting Review, 37 (2), 205229.

O’Dwyer, B., Owen, D. \& Unerman, J. (2011). Seeking legitimacy for new assurance forms: The case of assurance on sustainability reporting. Accounting, Organizations and Society, 36 (1), 31-52.

O’Dwyer, B., Unerman, J. \& Hession, E. (2005). User needs in sustainability reporting: perspective of stakeholders in Ireland. European Accounting Review, 14(3), 759-787.

Owen, D. L., Swift, T., Bowerman, M. \& Humphrey, C. (2000). The new social audits: Accountability, managerial capture or the agenda of social champions? European Accounting Review, 37 (2), 205-229.

Palmrose, Z., \& Scholz, S. (2004). The circumstances and legal consequences of non-GAAP reporting: Evidence from restatements. Contemporary Accounting Research, 21 (1), 139-180.

Perego, P. \& Kolk, A. (2012). Multinationals' accountability on sustainability: The evolution of third-party assurance of sustainability reports. Journal of Business Ethics, 110 (2), 173190.

Peters, G. F., \& Romi, A. M. (2015). The association between sustainability governance characteristics and the assurance of corporate sustainability reports. Auditing: A Journal of Practice \& Theory, 34 (1) 163-198.

Pfarrer, M. D., Smith, K. G., Bartol, K. M., Khanin, D. M. \& Zhan, X. (2008). Coming forward: the effects of social and regulatory forces on the voluntary restatement of earnings subsequent to wrongdoing. Organization Science, 19 (3), 386-403.

Pflugrath, G., P. Roebuck, \& Simnett, R. (2011). Impact of assurance and assurer's professional affiliation on financial analysts' assessment of credibility of corporate social responsibility information. Auditing: A Journal of Practice \& Theory 30 (3), 239-254.

Plumlee, M. \& Yohn, T. (2010). An analysis of underlying causes attributed to restatements. Accounting Horizons, 24 (1), 41-64.

Pomeroy, B. \& Thornton, D.B. (2008). Meta-analysis and the accounting literature: the case of audit committee independence and financial reporting quality. European Accounting Review, $17(2), 305-330$

Power, M. K. (1997). Expertise and the construction of relevance: Accountants and the environmental audit. Accounting, Organizations and Society, 22: 123-146. 
Power, M. K. (2003). Auditing and the production of legitimacy. Accounting, Organizations and Society, 28: 379-394.

Reimbsbach, D., Hahn, R. \& Gürtük, A. (2017). Integrated reporting and assurance of sustainability information: an experimental study on professional investors' information processing. European Accounting Review. DOI: 10.1080/09638180.2016.1273787

Salterio, S. E. (2012). Fifteen years in the trenches: Auditor-client negotiations exposed and explored. Accounting and Finance, 52 (Supplement), 233-286.

Simnett, R. A., Nugent, M. \& Huggins, A. L. (2009). Developing international assurance standards on greenhouse gas statements. Accounting Horizons, 23 (4), 347-363.

Simnett, R. A., Vanstraelen, A. \& Chua, W. F. (2009). Assurance on sustainability reports: An international comparison. The Accounting Review, 84 (3), 937-967.

Suchman, M. C. (1995). Managing legitimacy: strategic and institutional approaches. Academy of Management Review, 20 (3), 571-610.

Sustainability Accounting Standards Board (SASB). (2016). Materiality: Why is it important? Available online at: http://www.sasb.org/materiality/important/

Unerman, J., Bebbington, J. \& O'Dwyer, B. (2007). Introduction to sustainability accounting and accountability. In Unerman, J., J. Bebbington, and B. O'Dwyer (Eds.), Sustainability Accounting and Accountability. Routledge.

World Business Council for Sustainable Development (WBCSD). (2016). Assurance: Generating value from external assurance of sustainability reporting, WBCSD, Geneva, Switzerland. 
TABLE 1

Sample selection and characteristics

2010-2014

Panel A: Sample Selection

Initial sample of firm-year observations

Observations

Less:

Not issuing a stand-alone CSR report $\quad 1,106$

Reports not available $\quad 299$

Irregular reports 111

Control variables not available $\quad 100$

Total firm year observations available (reports analyzed) $\quad 1,200$

\begin{tabular}{lr}
\hline Unique firm observations & 372 \\
\hline
\end{tabular}

Panel B: Sample distribution over time

\begin{tabular}{rrrr} 
Year & Freq. & Percent & Cum. \\
\hline 2010 & 231 & 19.25 & 19.25 \\
2011 & 239 & 19.92 & 39.17 \\
2012 & 259 & 21.58 & 60.75 \\
2013 & 225 & 18.75 & 79.50 \\
2014 & 246 & 20.50 & 100.00 \\
\hline Total & 1200 & 100 &
\end{tabular}


TABLE 2

Restatement by year

\begin{tabular}{rrrr} 
Year & Number of Restatements & $\begin{array}{r}\text { Number of Reports with } \\
\text { Restatements }\end{array}$ & $\begin{array}{r}\text { \% Reports with } \\
\text { Restatement }\end{array}$ \\
\hline 2010 & 39 & 24 & $10.39 \%$ \\
2011 & 49 & 27 & $11.30 \%$ \\
2012 & 61 & 35 & $13.52 \%$ \\
2013 & 62 & 39 & $17.33 \%$ \\
2014 & 96 & 52 & $21.14 \%$ \\
\hline Total & 307 & 177 & \\
\hline
\end{tabular}




\section{TABLE 3}

\section{Instances of restatements}

Panel A: Breakdown of assurance and restatement

\begin{tabular}{|c|c|}
\hline Total observations & 1,200 \\
\hline Reports with assurance & 290 \\
\hline Reports with assurance provided by consulting firms & 226 \\
\hline Reports with assurance provided by accounting firms & 64 \\
\hline Reports with at least one restatement & 177 \\
\hline Reports with at least one error restatement & 116 \\
\hline Reports with at least one methodological update restatement ${ }^{(a)}$ & 72 \\
\hline Reports with at least one material restatement ${ }^{(b)}$ & 85 \\
\hline Reports with at least one non-material restatement ${ }^{(b)}$ & 98 \\
\hline
\end{tabular}

Panel B: Comparison of proportion of reports with a restatement across assurance groups

\begin{tabular}{lrrr}
\hline & Any Restatement & \multicolumn{1}{c}{$\begin{array}{c}\text { Error } \\
\text { Restatement }\end{array}$} & $\begin{array}{c}\text { Methodological } \\
\text { Update Restatement }\end{array}$ \\
\hline Reports including assurance & $99 / 290(34.1 \%)$ & $72 / 290(24.8 \%)$ & $36 / 290(12.4 \%)$ \\
Reports without assurance & $78 / 910(8.6 \%)$ & $44 / 910(4.8 \%)$ & $36 / 910(4.0 \%)$ \\
Chi-Square & 114.32 & 100.66 & 27.89 \\
Significance & $<.001$ & $<.001$ & $<.001$ \\
\hline
\end{tabular}

\begin{tabular}{lrr}
\hline & $\begin{array}{c}\text { Material } \\
\text { Restatement }^{(\mathrm{b})}\end{array}$ & \multicolumn{1}{c}{$\begin{array}{c}\text { Non-Material } \\
\text { Restatement }^{(\mathrm{b})}\end{array}$} \\
\hline Reports including assurance & $56 / 276(20.3 \%)$ & $58 / 276(21.0 \%)$ \\
Reports without assurance & $29 / 885(3.3 \%)$ & $40 / 885(4.5 \%)$ \\
Chi-Square & 89.75 & 74.07 \\
Significance & $<.001$ & $<.001$ \\
\hline
\end{tabular}

(a) Since each report may include more than one restatement, the sum of error and methodological update restatements is greater than 177 .

(b) We classify large restatements as those where the difference in reported data is more than five percent of the originally reported value. There are 39 cases in which we cannot assess the size of the, therefore the number of observations drops from 1,200 to 1,161 . 
TABLE 4

Descriptive statistics and correlation matrix

Panel A: Descriptive statistics

\begin{tabular}{lrrrrrr}
\hline Variables & N & \multicolumn{1}{c}{ Mean } & Std dev & \multicolumn{1}{c}{ Min } & Median & Max \\
\hline Report Size (pages) & 1,200 & 59.273 & 56.798 & 2 & 46 & 581 \\
GRI & 1,200 & 0.523 & 0.500 & 0 & 1 & 1 \\
Firm Size (log sales) & 1,200 & 9.413 & 1.168 & 6.745 & 9.337 & 11.969 \\
Sustainability Performance & 1,200 & 3.093 & 2.919 & 0 & 2 & 18 \\
ROA & 1,200 & 0.100 & 0.066 & -0.049 & 0.092 & 0.362 \\
LEV & 1,200 & 0.251 & 0.150 & 0.000 & 0.239 & 0.786 \\
ESSI & 1,200 & 0.287 & 0.452 & 0 & 0 & 1 \\
\hline
\end{tabular}

Panel B: Correlation Matrix

\begin{tabular}{|c|c|c|c|c|c|c|c|c|}
\hline & 1 & 2 & 3 & 4 & 5 & 6 & 7 & 8 \\
\hline 1 Restatement & 1.000 & & & & & & & \\
\hline 2 Assurance & $0.310 * * *$ & 1.000 & & & & & & \\
\hline 3 Report Size & $0.273 * * *$ & $0.332 * * *$ & 1.000 & & & & & \\
\hline 4 GRI & $0.252 * * *$ & $0.371 * * *$ & $0.427 * * *$ & 1.000 & & & & \\
\hline 5 Firm Size & $0.153 * * *$ & $0.125 * * *$ & $0.287 * * *$ & $0.108 * * *$ & 1.000 & & & \\
\hline 6 Sustainability & & & & & & & & \\
\hline Performance & $0.087 * *$ & $0.110 * * *$ & $0.187 * * *$ & $0.074^{*}$ & $0.486 * * *$ & 1.000 & & \\
\hline 7 ROA & 0.050 & -0.013 & -0.011 & $0.080 * *$ & 0.004 & -0.027 & 1.000 & \\
\hline $8 \mathrm{LEV}$ & -0.011 & 0.03 & $0.097 * * *$ & $0.077 * *$ & $-0.121 * * *$ & $0.067 *$ & $-0.071 *$ & 1.000 \\
\hline 9 ESSI & $0.085 * *$ & $0.074 *$ & $0.115 * * *$ & $0.174 * * *$ & -0.007 & $0.149 * * *$ & 0.031 & $0.140 * * *$ \\
\hline
\end{tabular}


TABLE 5

Logistic analysis of the impact of assurance on sustainability restatements

\begin{tabular}{lccccc}
\hline & $\begin{array}{c}\text { Any } \\
\text { restatement }\end{array}$ & Error & $\begin{array}{c}\text { Methodological } \\
\text { update }\end{array}$ & $\begin{array}{c}\text { Material } \\
\text { restatement }\end{array}$ & $\begin{array}{c}\text { Non-Material } \\
\text { restatement }\end{array}$ \\
\hline Assurance & $(1)$ & $(2)$ & $(3)$ & $(4)$ & $(5)$ \\
Report Size & $1.073^{* * *}$ & $1.328^{* * *}$ & $0.539^{*}$ & $1.341^{* * *}$ & $1.028^{* * * *}$ \\
& $(4.584)$ & $(4.726)$ & $(1.831)$ & $(4.581)$ & $(3.421)$ \\
GRI & $0.005^{* * *}$ & $0.004^{* * *}$ & $0.004 * * *$ & $0.005^{* * *}$ & $0.005 * * *$ \\
& $(3.308)$ & $(3.276)$ & $(3.065)$ & $(3.732)$ & $(3.901)$ \\
Firm Size & $1.004 * * *$ & $0.798^{* * *}$ & $0.920^{* * *}$ & $1.368^{* * *}$ & $1.080^{* * *}$ \\
& $(3.767)$ & $(2.665)$ & $(2.613)$ & $(3.233)$ & $(2.661)$ \\
Sustainability Performance & 0.162 & 0.236 & 0.049 & 0.162 & 0.203 \\
& $(1.592)$ & $(1.966)^{* *}$ & $(0.361)$ & $(1.126)$ & $(1.530)$ \\
ROA & 0.045 & 0.026 & 0.094 & -0.041 & 0.039 \\
& $(0.925)$ & $(0.492)$ & $(1.586)$ & $(-0.673)$ & $(0.602)$ \\
LEV & 2.391 & 1.468 & 2.741 & 2.825 & 3.074 \\
& $(1.427)$ & $(0.843)$ & $(1.070)$ & $(1.491)$ & $(1.455)$ \\
ESSI & -1.019 & -0.404 & $-1.876 *$ & -0.313 & -0.667 \\
& $(-1.340)$ & $(-0.472)$ & $(-1.670)$ & $(-0.334)$ & $(-0.686)$ \\
Constant & 0.247 & -0.064 & 0.392 & -0.201 & 0.307 \\
& $(1.005)$ & $(-0.215)$ & $(1.481)$ & $(-0.688)$ & $(1.036)$ \\
Year fixed effects & $-4.430^{* * *}$ & $-5.723 * * *$ & $-3.779 * * *$ & $-5.902 * * *$ & $-5.704 * * *$ \\
Observations & $(-4.401)$ & $(-4.699)$ & $(-2.599)$ & $(-4.279)$ & $(-4.112)$ \\
Pseudo R-squared & YES & YES & YES & YES & YES \\
\hline
\end{tabular}

Table 5 presents the result from regressing the likelihood of restatements (column 1), error (column 2), methodological update (column 3), material (column 4) and non-material (column 5) restatements on SRA presence. The table reports logistic coefficient estimates and (in brackets) robust z-statistics. Standard errors are clustered by firm. All other variables definitions are reported in Appendix 1. *,*, and *** represent significance levels of 0.10, 0.05, and 0.01 (two-tailed), respectively. 
TABLE 6

Logistic analysis of the impact of assurance by provider type on sustainability restatements

\begin{tabular}{lccccc}
\hline & $\begin{array}{c}\text { Any } \\
\text { restatement }\end{array}$ & Error & $\begin{array}{c}\text { Methodological } \\
\text { update }\end{array}$ & $\begin{array}{c}\text { Material } \\
\text { restatement }\end{array}$ & $\begin{array}{c}\text { Non-Material } \\
\text { restatement }\end{array}$ \\
\hline Consultant & $(1)$ & $(2)$ & $(3)$ & $(4)$ & $(5)$ \\
Accounting firm & $1.065^{* * *}$ & $1.345^{* * *}$ & $0.526^{*}$ & $1.353^{* * *}$ & $1.091^{* * *}$ \\
& $(4.186)$ & $(4.519)$ & $(1.693)$ & $(4.342)$ & $(3.523)$ \\
Report Size & $1.099^{* * *}$ & $1.269^{* * *}$ & 0.589 & $1.305^{* * *}$ & 0.796 \\
& $(3.153)$ & $(2.972)$ & $(1.269)$ & $(3.003)$ & $(1.518)$ \\
GRI & $0.005^{* * *}$ & $0.004^{* * *}$ & $0.004 * * *$ & $0.005^{* * *}$ & $0.005 * * *$ \\
& $(3.313)$ & $(3.231)$ & $(2.958)$ & $(3.714)$ & $(3.766)$ \\
Firm Size & $1.002^{* * *}$ & $0.802^{* * *}$ & $0.918^{* * *}$ & $1.370^{* * *}$ & $1.092^{* * *}$ \\
& $(3.761)$ & $(2.677)$ & $(2.601)$ & $(3.230)$ & $(2.698)$ \\
Sustainability Performance & 0.162 & $0.237 * *$ & 0.049 & 0.162 & 0.207 \\
& $(1.594)$ & $(1.977)$ & $(0.355)$ & $(1.132)$ & $(1.530)$ \\
ROA & 0.045 & 0.026 & 0.094 & -0.042 & 0.036 \\
& $(0.932)$ & $(0.480)$ & $(1.583)$ & $(-0.680)$ & $(0.566)$ \\
LEV & 2.382 & 1.493 & 2.729 & 2.845 & 3.162 \\
& $(1.418)$ & $(0.862)$ & $(1.062)$ & $(1.515)$ & $(1.509)$ \\
ESSI & -1.028 & -0.382 & $-1.895 *$ & -0.298 & -0.578 \\
& $(-1.335)$ & $(-0.438)$ & $(-1.680)$ & $(-0.313)$ & $(-0.600)$ \\
Constant & 0.251 & -0.075 & 0.399 & -0.209 & 0.271 \\
& $(0.994)$ & $(-0.242)$ & $(1.488)$ & $(-0.698)$ & $(0.894)$ \\
Year fixed effects & $-4.426^{* * *}$ & $-5.735^{* * *}$ & $-3.771^{* * *}$ & $-5.911 * * *$ & $-5.755^{* * *}$ \\
Observations & $(-4.414)$ & $(-4.731)$ & $(-2.577)$ & $(-4.318)$ & $(-4.096)$ \\
Pseudo R-squared & YES & YES & YES & YES & YES \\
\hline & 1,200 & 1,200 & 1,200 & 1,161 & 1,161 \\
Tabl 6 & 0.174 & 0.161 & 0.126 & 0.200 & 0.174 \\
\hline
\end{tabular}

Table 6 presents the result from regressing the likelihood of restatements (column 1), error (column 2), methodological update (column 3), material (column 4) and non-material (column 5) restatements on whether SRA is provided by a consulting or accounting firm. The table reports logistic coefficient estimates and (in brackets) robust z-statistics. Standard errors are clustered by firm. All other variables definitions are reported in Appendix 1. *,**, and *** represent significance levels of $0.10,0.05$, and 0.01 (two-tailed), respectively. 
TABLE 7

Propensity score matching

Panel A: Mean of covariates in the propensity score matching

\begin{tabular}{lrrrc}
\hline & $\begin{array}{c}\text { Assurance } \\
\text { sample }\end{array}$ & $\begin{array}{c}\text { Control } \\
\text { sample }\end{array}$ & \multicolumn{1}{c}{ t-stat } & \multicolumn{1}{c}{ p>t } \\
\hline GRI & 66.704 & 78.778 & -0.90 & 0.352 \\
Report Size & 0.741 & 0.704 & 0.30 & 0.767 \\
Firm Size & 9.414 & 9.688 & -0.90 & 0.368 \\
Sustainability Performance & 2.111 & 1.852 & 0.47 & 0.638 \\
ROA & 0.099 & 0.105 & -0.30 & 0.731 \\
LEV & 0.312 & 0.295 & 0.39 & 0.698 \\
ESSI & 0.333 & 0.370 & -0.20 & 0.781 \\
CSR committee & 0.815 & 0.889 & -0.70 & 0.453 \\
Membership to CSR Index & 0.481 & 0.481 & 0.00 & 1.000 \\
Bid-ask Spread & 0.011 & 0.011 & 0.04 & 0.972 \\
Audit Committee Size & 4.407 & 4.407 & 0.00 & 1.000 \\
Foreign Income & 0.556 & 0.593 & -0.20 & 0.788 \\
CEO Duality & 0.111 & 0.111 & -0.00 & 1.000 \\
n. of Board Meetings & 8.407 & 8.630 & -0.20 & 0.792 \\
Board Size & 11.370 & 11.407 & -0.00 & 0.932 \\
\% Independent Directors & 0.880 & 0.889 & -0.60 & 0.545 \\
Institutional Ownership & 0.889 & 0.926 & -0.40 & 0.646 \\
\hline
\end{tabular}


Panel B: Logistic regression on propensity score matched sample

\begin{tabular}{lccccc}
\hline & $\begin{array}{c}\text { Any } \\
\text { restatement }\end{array}$ & Error & $\begin{array}{c}\text { Methodological } \\
\text { update }\end{array}$ & $\begin{array}{c}\text { Material } \\
\text { restatement }\end{array}$ & $\begin{array}{c}\text { Non-Material } \\
\text { restatement }\end{array}$ \\
\hline Assurance & $1.228^{* * *}$ & $1.515^{* * *}$ & $0.617^{*}$ & $1.924^{* * *}$ & $1.110^{* * *}$ \\
Report Size & $(4.241)$ & $(4.316)$ & $(1.755)$ & $(4.184)$ & $(3.324)$ \\
GRI & $0.005^{*}$ & $0.005^{* *}$ & 0.003 & $0.005^{* *}$ & $0.004 * *$ \\
& $(1.941)$ & $(2.121)$ & $(1.314)$ & $(2.381)$ & $(2.136)$ \\
Firm Size & $0.878^{* *}$ & 0.736 & 0.353 & $1.997 * *$ & 0.397 \\
& $(2.050)$ & $(1.499)$ & $(0.719)$ & $(2.402)$ & $(0.736)$ \\
Sustainability & $0.312^{* *}$ & 0.293 & 0.177 & $0.556^{* *}$ & $0.309 *$ \\
Performance & $(2.011)$ & $(1.637)$ & $(0.974)$ & $(2.344)$ & $(1.829)$ \\
ROA & -0.030 & -0.037 & 0.060 & -0.135 & -0.045 \\
& $(-0.446)$ & $(-0.459)$ & $(0.739)$ & $(-1.210)$ & $(-0.560)$ \\
LEV & 0.606 & -0.773 & 2.044 & 1.615 & 2.327 \\
& $(0.249)$ & $(-0.269)$ & $(0.582)$ & $(0.668)$ & $(0.783)$ \\
ESSI & -1.612 & -1.016 & -2.467 & -1.717 & -1.061 \\
& $(-1.427)$ & $(-0.769)$ & $(-1.636)$ & $(-1.042)$ & $(-0.824)$ \\
Constant & 0.307 & -0.071 & 0.465 & 0.015 & 0.377 \\
& $(0.990)$ & $(-0.180)$ & $(1.215)$ & $(0.036)$ & $(1.018)$ \\
& $-5.167 * * *$ & $-5.454 * * *$ & $-5.242^{* * *}$ & $-10.134 * * *$ & $-5.922 * * *$ \\
Year fixed effects & $(-3.421)$ & $(-3.470)$ & $(-2.666)$ & $(-4.944)$ & $(-3.528)$ \\
Observations & YES & YES & YES & YES & YES \\
Pseudo R-squared & 372 & 372 & 372 & 352 & 352 \\
\hline
\end{tabular}

Table 7, Panel A provides means of the covariates for the treated (assurance) vs. control group of firms in the PSM sample. Panel B reports the logistic regression on the propensity score matched sample. Control variables definitions are reported in Appendix 1. The table reports logistic coefficient estimates and (in brackets) robust z-statistics. Standard errors are clustered at the firm level $*, * *$, and $* * *$ represent significance levels of $0.10,0.05$, and 0.01 (two-tailed), respectively. 
TABLE 8

Legitimacy of the assurance provider

Panel A. Likelihood to retain assurance provider

\begin{tabular}{|c|c|c|c|}
\hline & $(1)$ & (2) & (3) \\
\hline Restatement $_{(\mathrm{t}-1)}$ & $\begin{array}{c}0.787 \\
(1.793)^{*}\end{array}$ & & \\
\hline Error $_{(\mathrm{t}-1)}$ & & $\begin{array}{c}0.565 \\
(1.211)\end{array}$ & \\
\hline Methodological updates $_{(\mathrm{t}-1)}$ & & $\begin{array}{c}0.968 \\
(1.142)\end{array}$ & \\
\hline Material Restatement $(\mathrm{t}-1)$ & & & $\begin{array}{c}0.981 \\
(1.461)^{+}\end{array}$ \\
\hline Non-material Restatement $(\mathrm{t}-1)$ & & & $\begin{array}{c}0.288 \\
(0.560)\end{array}$ \\
\hline $\operatorname{Report~Size}_{(\mathrm{t}-1)}$ & $\begin{array}{c}0.007 \\
(1.716)^{*}\end{array}$ & $\begin{array}{c}0.007 \\
(1.732)^{*}\end{array}$ & $\begin{array}{c}0.006 \\
(1.621)\end{array}$ \\
\hline $\operatorname{Size}_{(\mathrm{t}-1)}$ & $\begin{array}{l}-0.568 \\
(-2.669) * * *\end{array}$ & $\begin{array}{l}-0.546 \\
(-2.551)^{* *}\end{array}$ & $\begin{array}{l}-0.619 \\
(-2.746)^{* * *}\end{array}$ \\
\hline $\operatorname{ROA}_{(t-1)}$ & $\begin{array}{c}0.171 \\
(0.069)\end{array}$ & $\begin{array}{c}0.229 \\
(0.093)\end{array}$ & $\begin{array}{c}1.078 \\
(0.445)\end{array}$ \\
\hline $\operatorname{LEV}_{(t-1)}$ & $\begin{array}{c}0.452 \\
(0.374)\end{array}$ & $\begin{array}{c}0.456 \\
(0.377)\end{array}$ & $\begin{array}{c}0.653 \\
(0.552)\end{array}$ \\
\hline ESSI & $\begin{array}{c}-0.827 \\
(-1.939)^{*}\end{array}$ & $\begin{array}{c}-0.806 \\
(-1.914)^{*}\end{array}$ & $\begin{array}{l}-0.949 \\
(-2.178)^{* *}\end{array}$ \\
\hline Governance Concerns $_{(\mathrm{t}-1)}$ & $\begin{array}{l}-0.428 \\
(-1.987)^{* *}\end{array}$ & $\begin{array}{l}-0.461 \\
(-2.189)^{* *}\end{array}$ & $\begin{array}{l}-0.490 \\
(-2.217)^{* *}\end{array}$ \\
\hline Governance Strengths $_{(\mathrm{t}-1)}$ & $\begin{array}{c}0.584 \\
(1.787)^{*}\end{array}$ & $\begin{array}{c}0.573 \\
(1.770)^{*}\end{array}$ & $\begin{array}{c}0.556 \\
(1.628)\end{array}$ \\
\hline Social and environmental concerns $(\mathrm{t}-1)$ & $\begin{array}{l}0.308 \\
(2.985)^{* * *}\end{array}$ & $\begin{array}{l}0.298 \\
(2.854)^{* * *}\end{array}$ & $\begin{array}{l}0.360 \\
(3.325)^{* * *}\end{array}$ \\
\hline Constant & $\begin{array}{l}3.986 \\
(2.320) * *\end{array}$ & $\begin{array}{l}3.884 \\
(2.264) * *\end{array}$ & $\begin{array}{l}4.273 \\
(2.297)^{* *}\end{array}$ \\
\hline Year fixed effects & YES & YES & YES \\
\hline Observations & 217 & 217 & 210 \\
\hline Pseudo R-squared & 0.127 & 0.125 & 0.135 \\
\hline
\end{tabular}


Panel B. Likelihood to increase number of clients

\begin{tabular}{|c|c|c|c|}
\hline & $(1)$ & (2) & (3) \\
\hline Restatement $_{(\mathrm{t}-1)}$ & $\begin{array}{l}1.116 \\
(1.962)^{* *}\end{array}$ & & \\
\hline $\operatorname{Error}_{(\mathrm{t}-1)}$ & & $\begin{array}{c}0.468 \\
(0.836)\end{array}$ & \\
\hline Methodological updates $(t-1)$ & & $\begin{array}{l}1.316 \\
(2.128) * *\end{array}$ & \\
\hline Material Restatement $_{(\mathrm{t}-1)}$ & & & $\begin{array}{c}1.112 \\
(1.749)^{*}\end{array}$ \\
\hline Non-material Restatement $(\mathrm{t}-1)$ & & & $\begin{array}{c}-0.184 \\
(-0.275)\end{array}$ \\
\hline Accounting firm & $\begin{array}{c}0.450 \\
(0.696)\end{array}$ & $\begin{array}{c}0.625 \\
(0.963)\end{array}$ & $\begin{array}{c}0.515 \\
(0.800)\end{array}$ \\
\hline Constant & $\begin{array}{l}-2.357 \\
(-3.190) * * *\end{array}$ & $\begin{array}{l}-2.341 \\
(-3.185) * * *\end{array}$ & $\begin{array}{l}-1.991 \\
(-2.894) * * *\end{array}$ \\
\hline Year fixed effects & YES & YES & YES \\
\hline Observations & 96 & 96 & 95 \\
\hline R-squared & 0.119 & 0.132 & 0.112 \\
\hline
\end{tabular}

Table 8 presents evidence on the legitimacy of the assurance providers. Panel A presents results where we regress the likelihood to retain the assurance provider on the presence of at least one restatement (column 1), one error or methodological update (column 2), and one material or non-material restatement (column 3). All independent variables are lagged at $\mathrm{t}-1$. The table reports logistic coefficient estimates and (in brackets) robust z-statistics. Standard errors are clustered by firm. Panel B presents results where we regress the likelihood of increasing the number of clients on the presence of at least one restatement (column 1), one error or methodological update (column 2), and one material or nonmaterial restatement (column 3). The table reports logistic coefficient estimates and (in brackets) z-statistics. Governance concerns and strengths are respectively the KLD Corporate Governance Strengths and Concerns Scores, while Social and Environmental Concerns are equal to the sum of the KLD Concerns scores in the following areas: Community, Employee Relations, Human Rights, Diversity, Product Responsibility, Environment. All other variable definitions are reported in Appendix 1.

${ }^{+}$represent significance level of 0.10 (one-tailed), * **, and *** represent significance levels of $0.10,0.05$, and 0.01 (twotailed), respectively. 


\section{Appendix 1 \\ Variable definitions}

\begin{tabular}{|c|c|}
\hline \multicolumn{2}{|r|}{ Restatement variables } \\
\hline Restatement & dummy equal to 1 if the firm discloses any restatement; 0 otherwise; \\
\hline Error & $\begin{array}{l}\text { dummy equal to } 1 \text { if the firm discloses at least one restatement due to } \\
\text { error; } 0 \text { otherwise; }\end{array}$ \\
\hline Methodological update & $\begin{array}{l}\text { dummy equal to } 1 \text { if the firm discloses at least one restatement due to a } \\
\text { methodological update; } 0 \text { otherwise; }\end{array}$ \\
\hline Material restatement & $\begin{array}{l}\text { dummy equal to } 1 \text { if the firm discloses at least one restatement due to } \\
\text { error of magnitude greater or equal to a } 5 \% \text { change in the data; } 0 \\
\text { otherwise; }\end{array}$ \\
\hline Non-material restatement & $\begin{array}{l}\text { dummy equal to } 1 \text { if the firm discloses at least one restatement due to } \\
\text { error of magnitude less than a 5\% change in the data; } 0 \text { otherwise; }\end{array}$ \\
\hline \multicolumn{2}{|r|}{ Assurance variables } \\
\hline Assurance & $\begin{array}{l}\text { dummy equal to } 1 \text { if the firm purchases external assurance for the entire } \\
\text { sustainability report or for specific items; } 0 \text { otherwise; }\end{array}$ \\
\hline Accounting firm & $\begin{array}{l}\text { dummy equal to } 1 \text { if the firm purchases external assurance from an } \\
\text { accounting firm; } 0 \text { otherwise; }\end{array}$ \\
\hline Consultant & $\begin{array}{l}\text { dummy equal to } 1 \text { if the firm purchases external assurance from a } \\
\text { consulting firm; } 0 \text { otherwise; }\end{array}$ \\
\hline \multicolumn{2}{|r|}{ Control variables } \\
\hline Report Size & length of report, measured by pages; \\
\hline GRI & \\
\hline Firm Size & natural log of total sales; \\
\hline Sustainability Performance & $\begin{array}{l}\text { KLD total concerns score (governance, community, diversity, employee } \\
\text { relations, environment, human rights, and product); }\end{array}$ \\
\hline$R O A$ & $\begin{array}{l}\text { return on assets measured as the ratio of income before extraordinary } \\
\text { items to total assets at the beginning of each year; }\end{array}$ \\
\hline$L E V$ & ratio of total debt to total assets; \\
\hline ESSI & $\begin{array}{l}\text { dummy equal to } 1 \text { if firm is in environmental or social sensitive industry, } \\
0 \text { otherwise; }\end{array}$ \\
\hline \multicolumn{2}{|r|}{ Additional variables in PSM } \\
\hline CSR committee & dummy equal to 1 if there is a CSR committee; 0 otherwise; \\
\hline Membership to CSR Index & dummy equal to 1 if the company is listed in a CSR index; 0 otherwise; \\
\hline Bid-ask Spread & $\begin{array}{l}\text { average of daily effective bid-ask spreads during quarter } t \text {, where the } \\
\text { effective bid-ask spread is measured as two times the absolute value of } \\
\text { the difference between the daily ending trading price and the average of } \\
\text { the ask and bid, scaled by the average of ask and bid; }\end{array}$ \\
\hline Audit Committee Size & total number of members on the audit committee; \\
\hline Foreign Income & $\begin{array}{l}\text { dummy equal to } 1 \text { if a firm has income from foreign operations in a } \\
\text { given year, } 0 \text { otherwise; }\end{array}$ \\
\hline CEO Duality & $\begin{array}{l}\text { dummy equal to } 1 \text { if the CEO is also the Chairman of the board; } 0 \\
\text { otherwise; }\end{array}$ \\
\hline n. of Board Meetings & total number of board meetings in each year; \\
\hline Board Size & total number of board members; \\
\hline$\%$ Independent Directors & proportion of independent directors to total directors; \\
\hline Institutional Ownership & $\%$ of shares held by institutional investors. \\
\hline
\end{tabular}


Online Supplemental Material to

\title{
Creating Legitimacy for Sustainability Assurance Practices: Evidence from
} Sustainability Restatements

\author{
Giovanna Michelon \\ University of Exeter Business School \\ Streatham Court, Rennes Drive \\ Exeter, UK EX4 4ST \\ G.Michelon@exeter.ac.uk \\ ORCID ID: 0000-0003-0107-9809 \\ Dennis M. Patten \\ Illinois State University \\ Department of Accounting \\ Normal, IL 61761 \\ dmpatte@ilstu.edu \\ Andrea M. Romi \\ Texas Tech University \\ Rawls College of Business \\ Department of Accounting \\ Box 42101 \\ Lubbock, TX 79409-2101 \\ Andrea.Romi@ttu.edu \\ ORCID ID: 0000-0002-4138-0068
}




\section{Reconciliation of KPMG 2013 sample to our 2013 sample}

\begin{tabular}{lc} 
& Observations \\
\hline Initial sample of firm-year observations KPMG & 99 \\
Less: & 31 \\
KPMG sample firm not included in our sample due to attrition & 14 \\
$\quad$ described in Table 1 & 40 \\
KPMG sample not issuing a stand-alone CSR report & 5 \\
KPMG reports no restatement, we agree & 6 \\
KPMG reports no restatement, we find a restatement & 3 \\
KPMG reports restatement due to factor other than error, we & find the restatement is an error \\
$\quad$ agree & 0 \\
\hline FPMG reports restatement due to factor other than error, we & \\
\hline Firms remaining in KPMG U.S. sample &
\end{tabular}

We obtained private information from KPMG regarding the data for the firms responding to their 2013 questionnaire and were able to isolate the U.S. results from the global results. There are differences between our sample and KPMG's, attributable mainly to scope and methodological differences, as well as the fact that KPMG provides restatement results on a global basis for only the largest 100 firms in each country and we focus on U.S. S\&P 500 firms. Within KPMG's (2013) survey, there is one question pertaining to restatements, asking whether the firm's report discusses changes in previous years' data and provides the following as possible reasons for that change: A. Restatements due to error or omission, B. Restatements due to updated (improved) estimation/calculation methodology, C. Update of definitions applied, D. Update of scope (not relating to change in acquisition/divestments), and/or E. Other (please specify).

One difference between our methodology and that of KPMG is that we actually analyze each firm's sustainability report for discussions of changes in the previous years' data instead of relying on management's own admission about whether they have a restatement (i.e. questionnaire response). Additionally, KPMG states they rely on "Reports published between mid-2012 and mid-2013 ... If a company did not report during this period, information from 2011 was used" (KPMG 2013, 6). Therefore, KPMG's report may include information for 2011, 2012, or 2013 depending on the timing of the questionnaire and the firm's specific reporting year (companies have scheduled sustainability reporting years similar to fiscal years for financial reporting and these vary). Given the differences in scope and methodology, we reconcile our 2013 restatement sample with KPMG.

KPMG's sample includes 99 U.S. firms, 14 of which do not provide a sustainability report and 31 of which were not included in our sample for that particular year (of these KPMG reported 3 restatements due to methodological updates). Additionally, 40 of these reports had no restatements, to which we agreed. Of the remaining 14 firms, KPMG reported 5 firms who responded to the questionnaire that they did not have a restatement, but we found restatements of errors within their reports. An example is one firm with three separate restatements utilizing the same description, "Data for previous years has been revised since the 2011 Corporate Citizenship Interim Report, to reflect corrections made as a result of internal reviews." KPMG also provided 6 firms who answered yes to the restatement question and offered reasons other than errors for the restatement and we found that those restatements were actually due to errors. An example of this is one firm with the following language associated with their restatement in their sustainability report, "In 2013, we identified a significant error in our waste and recycling reporting, which resulted in a major restatement of our waste diversion rate for 2011 and 2012." Finally, there were 3 firms KPMG listed as having a restatement due to a methodological update with which we agreed. The reconciliation of these differences between our samples alters KPMG's reported restatement rates of 14 percent (12 methodological updates) to a restatement rate of 26 percent (11 errors, 3 methodological updates), which is more closely aligned with our larger sample reporting a restatement of 17 percent (24 errors, 16 methodological updates). 


\section{Sustainability Restatement Examples}

Restatement due to error: Baxter (2011, p. 94)

"Subsequent to publishing the 2009 Sustainability Report, the company received information from facilities to permit exceedances that warrant correction for 2006-2009. Instead of a $29 \%$ reduction on environmental incidents from 2005 to 2009, the corrected data shows a $7 \%$ increase during the period".

\section{0}

Sustainability Report

Baxter has a goal to decrease environmental compliance incidents $75 \%$ by 2015 , compared to 2005 . While Baxter has not made progress against this goal, it has reaffirmed its commitment to focus on reducing compliance incidents through 2015. Additionally, as in 2010. nearly all of the incidents occurred at a few facilities, as noted in the table below. The company's Lessines, Belgium, facility reported 35 wastewater exceedances. These were primarily temperature exceedances, in which the temperature varied within three degrees Celsius above the permit limit. In addition, Baxter's Sabiñánigo, Spain, facility reported 25 wastewater exceedances, primarily involving increased flow of treated wastewater. Both facilities continue to work with internal and external resources to address these issues.

\begin{tabular}{|l|r|r|r|r|r|}
\hline Environmental Compliance Incidents* & \multicolumn{2}{|l|}{} \\
\hline & 2007 & 2008 & 2009 & 2010 & 2011 \\
\hline Air & 1 & 1 & 4 & 0 \\
\hline Land & 1 & 1 & 1 & 1 \\
\hline Drinking Water & 0 & 0 & 0 & 0 \\
\hline Wastewater & 32 & 33 & 39 & 67 & 73 \\
\hline Total & 34 & 35 & 44 & 70 & 74 \\
\hline
\end{tabular}

'Subsequert to publishing Baxter's 2009 Sustainability Report, the company received information ffom its facilfes related to permit exceedances that warrarted correcton of 2006 - 2009 data. Inelead of a $29 \%$ reduction in environmental incidents from 2005 to 2009 the corrected data show a $7 \%$ increase during that period.

As illustrated in the table above, most of Baxter's environmental compliance incidents have been related to wastewater. The graph (below) provides a breakdown of wastewater incidents by type in 2011.

\section{Wastewater Environmental Compliance Incidents, 2011}

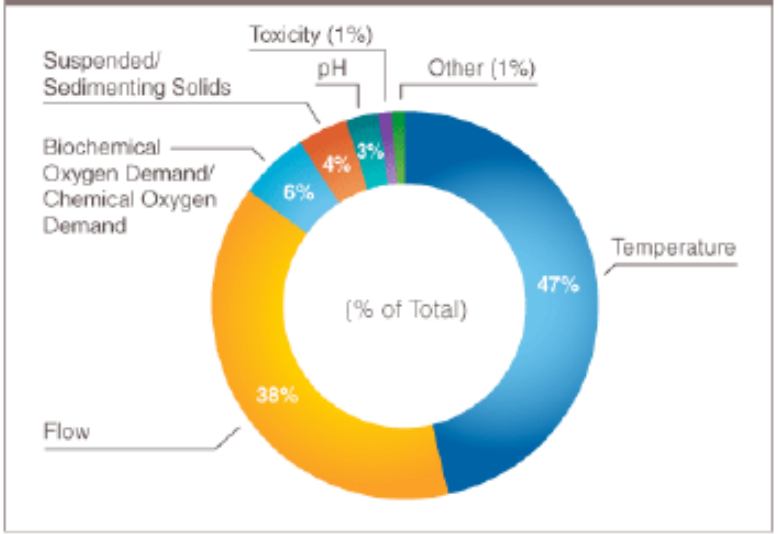

In 2011 , approximately $85 \%$ of Baxter's wastewaterrelated compliance incidents involved discharges to surface waterways, such as rivers, streams or creeks. The remaining $15 \%$ occurred at facilities that discharge to regional or municipal wastewater treatment systems.

At Lessines and Sabinánigo, the regulatory agencies involved generally viewed Baxter's responses to the exceedances as sufficient and have not pursued enforcement activities. In the case of Castlebar, Ireland, Baxter is in ongoing communication with the agency to address its concerns. Baxter continues to apply internal and external legal and engineering resources to evaluate compliance and technical solutions at high-risk facilities. See Water and Wastewater for more detail. 
Restatement due to methodological update: General Mills (2014, p. 102)

“*** Some data are restated compared to reporting in prior years to reflect improvements in data gathering and tracking methodology” (restated data is reflected in table with $* * *$ ).

\begin{tabular}{|c|c|c|c|c|c|c|c|c|c|c|}
\hline \multicolumn{11}{|c|}{ Environmental Data Summary $y^{\star, \star \star, \star \star \star \star}$} \\
\hline In thousands, except rate data & 2005 & 2006 & 2007 & 2008 & 2009 & 2010 & 2011 & 2012 & $\begin{array}{l}2013 \text { Excl } \\
\text { Yoplate/Yokb }\end{array}$ & $\begin{array}{l}2013 \text { ind } \\
\text { Yophat// ok }\end{array}$ \\
\hline Energy usage rate (kWl/metric ton of product) & 580 & $5 / 0$ & 579 & 551 & 546 & 534 & 533 & 528 & 531 & 524 \\
\hline Energy usage (kWh) EN3, EN4 & $2,769,236$ & $2,740,885$ & $2,738,032$ & $2,754,677$ & $2,685,422$ & $2,656,939$ & 2,601972 & $2,465,000$ & 2506,426 & 2931,196 \\
\hline Diroct energy usage by primary source $(\mathrm{KWh})$ & 1509,968 & 1511,989 & $1,527,708$ & $1,496,014$ & $1,47,627$ & $1,509,856$ & $1,462.563$ & $1,358,567$ & $1,391,133$ & $1,644,732$ \\
\hline Fuel oil $(\mathrm{kWh})$ & 50.237 & 58,580 & 37,242 & 29.597 & 24,992 & 23.556 & 22,055 & 21,249 & 22.586 & 26,90 \\
\hline Natural gas (kWh) & $1,414,5 / 3$ & $1,370,316$ & $1,405,408$ & $1,379,694$ & $1,37,570$ & $1,382,944$ & 1,350,699 & 1,267,482 & $1,284,875$ & $1,386,492$ \\
\hline LPgas (KWh) & 4,484 & 5,846 & 4,787 & 2,989 & 14,458 & 17,085 & 4,17 & 2747 & 2,013 & 29,042 \\
\hline Solar panels (kWh) & NA & NA & NA & NA & NA & NA & 82 & 121 & 119 & 119 \\
\hline Cogenereration electric $(\mathrm{kWh})$ & 14,146 & 19,129 & 21,128 & 20,744 & 14,672 & 27,221 & 25,234 & 77,63 & 17,87 & $7,8 n$ \\
\hline Cogeneration steam (QWh) & 26,528 & 58,17 & 59,143 & 62989 & 40,736 & 56,698 & 52,330 & 30,646 & 39,348 & 39,348 \\
\hline Biomass (kWh) & NA & $\mathrm{NA}$ & NA & NA & NA & 2.352 & 7,993 & 18,559 & 24,322 & 144949 \\
\hline Indirect energy consurmption (eloctricity) (kWh) & $1,259,268$ & $1,228,897$ & 1,210,325 & $1,258,603$ & 1,213,794 & 1,477,082 & 1,139,408: & $, 006,444$ & 1,15,293 & $1,286,465$ \\
\hline International (aWh) & 104,083 & 710,689 & 125,176 & 788,336 & 159,683 & 138,470 & 140,497 & 149,890 & 156,838 & 326,841 \\
\hline NorthAmerica $(\mathrm{kWh})$ & 1.155,185 & 1,198,207 & 1,085,448 & $1,080,267$ & $1,054,112$ & $1,008,612$ & 998,911 & 956,554 & 958,455 & 958,455 \\
\hline \multicolumn{11}{|l|}{ Energy usage, by region } \\
\hline International (kWh) & 215,202 & 253,647 & 284,709 & 291,888 & 264,858 & 262493 & 268,289 & 283,768 & 294,718 & 78,319 \\
\hline North America $(\mathrm{kWW})$ & $2,554,025$ & $2,487,239$ & $2,453,324$ & $2,462,729$ & $2,420,564$ & $2,394,446$ & $2,333,683$ & $2,181,243$ & $2,211,709$ & $2,211,709$ \\
\hline GHG enissions rate (metric tons $\mathrm{CO}_{2} \mathrm{e} /$ & 0225 & 0.27 & 0224 & & 0271 & 0204 & 0205 & 0205 & 0205 & 0181 \\
\hline GHG enissions (Scopes 1 and 2) (metric tons COZe) & 1,073 & 1,065 & 0.205 & 0,064 & 0.203 & 1014 & 1.002 & 9.205 & 968 & 1,011 \\
\hline Scope 1 (metric tons COZ2e) EN16 & 280 & 283 & 285 & 282 & 273 & 285 & 273 & 251 & 255 & 282 \\
\hline Fued oll (metric tons $\mathrm{CO} 2 \mathrm{e}$ ) & 12 & 14 & 8 & 7 & 5 & 5 & 5 & 4 & 5 & 6 \\
\hline Natural gas (metric tons $\mathrm{CO} 2 \mathrm{e}$ ) & 267 & 268 & 275 & 274 & 265 & 277 & 267 & 246 & 250 & 270 \\
\hline LP gas (metric tons COZe) & 1 & 1 & 1 & 1 & 3 & 4 & 1 & 1 & 0 & 6 \\
\hline Scope 2 (metric tons $\mathrm{CO22}$ ) ENI6 & 793 & 782 & 774 & 782 & 760 & 728 & 730 & 707 & 73 & 729 \\
\hline GHG entissiors from reneweweles (not in Scope lor 2) & NA & NA & NA & NA & NA & 0 & 1 & 3 & 4 & 44 \\
\hline \multicolumn{11}{|l|}{ GHG Emissions, by region } \\
\hline International (metric tons $\mathrm{CO} 2 \mathrm{e}$ ) & 64 & 76 & 86 & 85 & 84 & 87 & 91 & 95 & 100 & 143 \\
\hline North America (metric tors COZe) & 1,009 & 989 & $9 / 3$ & 979 & 950 & 927 & 912 & 863 & 868 & 868 \\
\hline Water usage rate (cubicic meters/metric ton of product) & & 2383 & 2.266 & 2222 & 2258 & 2186 & 2112 & 2135 & $2 \mathrm{~m}$ & 2902 \\
\hline Water withdrawl (cubicic meters) EN8 & & 11,100 & 10,600 & 11,000 & 11,000 & 10,800 & 10,300 & 10,000 & 10,000 & 16,200 \\
\hline Groundwater (abic meters) & NA & NA & NA & NA & NA & NA & 2000 & 1,800 & ,, 700 & 4,00 \\
\hline Municipal (cubic melers) & NA & NA & NA & NA & NA & NA & 8,300 & 8,200 & 8300 & 8,400 \\
\hline Surface water (cubic meters) & NA & NA & NA & NA & NA & NA & NA & NA & NA & 3,700 \\
\hline $\begin{array}{l}\text { Soldid waste generation rate (metric torsed } \\
\text { metric tons of product) }\end{array}$ & 0.057 & 0.052 & 0.047 & 0.051 & 0.040 & 0.037 & 0.037 & 0.034 & 0.033 & 0.034 \\
\hline Soldd waste (metric tons) EN22 & 266 & 241 & 221 & 239 & 197 & 183 & 178 & 159 & 155 & 190 \\
\hline
\end{tabular}

